Jacek Puchalski

Warszawa

\title{
Prace Józefa Grycza nad organizacją bibliotekarstwa publicznego w latach 1945-1949 \\ Część II
}

\section{Problem doboru i kontroli księgozbiorów bibliotek powszechnych}

W referacie Rola biblioteki i bibliotekarza w Polsce wspótczesnej... wygłoszonym w październiku 1945 r. Adam Łysakowski podkreślał, że zbiory samorządowych bibliotek publicznych stanowiły ówcześnie jedyne źródło powszechnie dostępnej lektury1. Dlatego głosił konieczność „wyzyskania" książek ocalałych z pożogi wojennej - ok. $11 \%$ przedwojennych zbiorów bibliotecznych ${ }^{2}$. Zwracał przy tym uwagę na problem właściwego zagospodarowania tzw. zbiorów „opuszczonych i porzuconych”3.

Niniejszy tekst stanowi kontynuację artykułu opublikowanego w poprzednim tomie „Z badań nad książką i księgozbiorami historycznymi” (5:2011, s. 53-88), w którym przedstawiono udział J. Grycza w powojennych pracach nad ustawą „o bibliotekach”.

${ }^{1}$ A. Lysakowski, Rola biblioteki i bibliotekarza w Polsce wspótczesnej. Aktualne zagadnienia bibliotekarskie, [w:] Pierwsza powojenna konferencja okręgowych wizytatorów bibliotek $w$ dniach 24-27 października 1945 r. w Pabianicach, Warszawa 1946 (dalej cyt. A. Łysakowski, Rola biblioteki...), s. 18.

${ }^{2}$ B. Bieńkowska, Potyczki ze źródtami bibliologicznymi (na przyktadzie urzędowej dokumentacji strat bibliotek $w$ Polsce podczas II wojny światowej), „Roczniki Biblioteczne”, 41:2001, s. 23.

${ }^{3}$ A. Łysakowski, Rola biblioteki..., s. 21. Księgozbiory „opuszczone i porzucone” o profilu powszechnym oraz druki regionalne trafiały do bibliotek publicznych, zob. P. Lechowski, Problemy $i$ organizacja powszechnego bibliotekarstwa publicznego $w$ Polsce w latach 1945-1951, „Roczniki Biblioteczne”, 55:2011 (dalej cyt. P. Lechowski, Problemy...), s. 98-99. 
Zadania te częściowo wypełniała Centrala Zakupu Książek, działająca w Warszawie od wiosny 1945 r. Oprócz nowości wydawniczych gromadziła ona wydawnictwa pochodzące $\mathrm{z}$ przedwojennych księgozbiorów i rozdzielała je między biblioteki, najczęściej powiatowe i gminne ${ }^{4}$. Kolejnym źródłem uzupełniania zbiorów bibliotecznych były dary i zbiórki publiczne książek. W efekcie księgozbiory bibliotek powszechnych stanowiły w dużej części „zbieraninę” przypadkowych wydawnictw. A przecież, zgodnie z założeniami władz bibliotecznych, miały być zaopatrzone w „dobrą” książkę, tj. „odpowiednią”, „pożądaną”, „,społecznie użyteczną" . Sposób, w jaki radziła sobie z tym problemem Naczelna Dyrekcja Bibliotek (NDB) Ministerstwa Oświaty pod kierownictwem J. Grycza, rzutował zarówno na ocenę realizacji ,akcji bibliotecznej” przez władze zwierzchnie, jak i na ocenę pracy NDB oraz samego J. Grycza. Dlatego kwestia doboru i kontroli księgozbiorów bibliotek powszechnych tworzonych po II wojnie światowej zasługuje na odrębne omówienie.

Materiały J. Grycza ${ }^{6}$ ukazują ewolucję pojęcia „dobrej książki” w pracach Wydziału Bibliotek, a później NDB. Zachowały się w nich m.in. spisy wydawnictw ,pożądanych” w księgozbiorach bibliotek gminnych (wiejskich i miejskich) i powiatowych. Wśród nich znajduje się anonimowy spis zatytułowany Najmniejsza biblioteka na wsi (200 ksiażek), pochodzący prawdopodobnie z 1945/46 r. Zawierał m.in. publikacje umieszczone wkrótce na wykazach , książek podlegających niezwłocznemu wycofaniu" z księgozbiorów bibliotecznych ${ }^{7}$ - np. wydawnictwa religijne oraz dzieła Ferdynanda Goetla, Ferdynanda Antoniego Ossendowskiego i Józefa Piłsudskiego. Autor spisu wskazywał również na:

brak odpowiednich książek z życia obyczajowego w obcych krajach [...] brak powieści z życia naszej emigracji, powieści osnutych na przygodach naszych podróżników. Prócz tego bardzo pożądane są utwory o prawdzie życia i czyny ludzi, których losy i działalność były ciekawe i niezwykłe (ulubiony typ lektury na wsi)

${ }^{4}$ Cz. Gutry, Centralna Zbiornica Ksiażek, „Bibliotekarz”, październik 1945, nr 1 (dalej cyt. Cz. Gutry, Centralna Zbiornica...), s. 12-13; AAN, Ministerstwo Oświaty (dalej cyt.: MOśw.), Naczelna Dyrekcja Bibliotek (dalej cyt.: NDB), 6847, Tymczasowy regulamin Centrali Zakupu Książek. [Projekt, 1945 r]; Na temat funkcjonowania tej instytucji w latach 1945-1949 zob. [Sprawozdanie z działalności Centralnej Zbiornicy Książek przy Naczelnej Dyrekcji Bibliotek Ministerstwa Oświaty, Warszawa 1949], tamże.

5 J. Grycz, Co wnosi polska ustawa biblioteczna? „Bibliotekarz”, październik 1945, nr 1, s. 5.

${ }^{6}$ Przechowywane w Oddziale Rękopisów BN.

7 AAN, MOśw., NDB, 6979, Wykazy „książek podlegających niezwłocznemu wycofaniu”; BN, rps akc. 14927 (dalej cyt.: BN, rps akc. 14927), t. 5., J. Grycz, Praca w Naczelnej Dyrekcji Bibliotek (1946-1949). 
[...]. Brak opracowania popularnego omawiającego zagadnienia ustrojowe w różnych państwach, oraz główne kierunki polityczne. B. potrzebne! ${ }^{8}$

Oczywiście autor spisu zdawał sobie sprawę, że „pożądane byłyby książki z życia współczesnej wsi i świata pracy”, wyjaśniając równocześnie, że „prawie zupełnie brak tego typu książek” na rynku księgarskim. Kilka pozycji z literatury politycznej znalazło się natomiast na liście 50 pozycji zalecanych dla bibliotek powiatowych.

Kolejne zestawienie nosiło tytuł Książki pożadane w oświatowych bibliotekach publicznych (Miejskich). Także i tutaj znalazły się dzieła szeregu niebawem zakazanych autorów, np. Jędrzeja Giertycha i Feliksa Konecznego. Wykaz zalecał bibliotekom miejskim gromadzenie beletrystyki na dobrym poziomie artystycznym oraz „unikanie wyraźnej tendencji i jaskrawo występujących celów dydaktycznych. Czytelnik, o którym mowa, natychmiast je wyczuwa i podchwytuje - zraża się i traci zaufanie do książki"9.

Autor spisu również wskazywał na brak w ofercie wydawniczej dobrych powieści odzwierciedlających „prądy kulturalne i zagadnienia ostatnich czasów”, a zwłaszcza dotyczących życia „nowej” wsi, świata robotniczego i inteligenckiego. Wykaz zawierał za to kilka dzieł polskich marksistów ${ }^{10}$.

Późniejsze (z 1948 r.) spisy książek „pożądanych” - znajdujące się w materiałach J. Grycza - były już pozbawione publikacji uznanych za „szkodliwe”. Zawierały natomiast dużą ilość przekładów sowieckiej beletrystyki oraz piśmiennictwa marksistowsko-leninowskiego ${ }^{11}$.

Budowanie księgozbiorów bibliotecznych miało z czasem opierać się na ofercie ruchu wydawniczego. Dlatego już w 1945 r. przewidywano opracowanie i wdrożenie państwowego, ogólnopolskiego, „racjonalnego" planu wydawniczego ${ }^{12}$. J. Grycz zakładał, że na jego ustalenie i realizację może wpływać ogólnokrajowa sieć samorządowych bibliotek powszechnych. Spodziewał się bowiem, że to od użytkowników księgozbiorów sieci „wyjdzie «zamówienie społeczne», które wskaże, jakie dzieła, w jakiej formie, w jakich ilościach i w jakich terminach należy wyprodu-

${ }^{8}$ BN, rps akc. 14927, t. 5, Najmniejsza biblioteka na wsi (200 książek).

${ }^{9} \mathrm{BN}$, rps akc. 14927, t. 5, Książki pożądane w oświatowych bibliotekach publicznych (Miejskich).

${ }^{10} \mathrm{~W}$ spisie znalazły się dzieła Ludwika Krzywickiego i Edwarda Abramowskiego, zob. BN, rps akc. 14927, t. 5, Książki pożądane w oświatowych bibliotekach publicznych (Miejskich).

${ }^{11} \mathrm{BN}$, rps akc. 14927 , t. 5.

12 A. Łysakowski, Rola biblioteki..., s. 21. 
kować"13. Owo zamówienie miały realizować biblioteki zaopatrywane centralnie przez Ministerstwo Oświaty ${ }^{14}$, równocześnie wpływając na ofertę wydawców:

Gdy będziemy mogli z góry zamówić dla bibliotek po kilka tysięcy egzemplarzy danej książki, będziemy mogli zażądać wydania jej w ustalonej formie (papier, format, czcionki, wyposażenie graficzne, ewentualnie oprawa nakładowe itd.), będziemy mogli wpłynąć na cenę. Odbije się to nie tylko na książkach przeznaczonych dla bibliotek, lecz w ogóle na całym rynku wydawniczym. Odbudowa bibliotek będzie równocześnie popierała odbudowę polskiej książki, poprzez subwencjonowanie konsumpcji wspierać będziemy produkcję ${ }^{15}$.

Koncepcję J. Grycza szybko zweryfikowała rzeczywistośćc ${ }^{16}$. Już w 1949 r. stwierdził, że:

produkcja [wydawnicza] bieżąca nadaje się zaledwie w pewnym procencie do bibliotek, a wpływanie na państwowy plan wydawniczy drogą tzw. zamówienia społecznego ze strony bibliotek nie znalazło jeszcze właściwej formy i skuteczności

${ }^{13} \mathrm{BN}$, rps akc. 14927, t. 3, J. Grycz, O realizacje ustawy bibliotecznej, (dalej cyt. J. Grycz, O realizacje ustawy bibliotecznej...). Artykuł został opublikowany w „Odrodzeniu" 1948, nr 2.

14 Już w październikowym numerze „Bibliotekarza” z 1945 r. Czesław Gutry wyjaśniał, iż Centralna Zbiornica Książek jako agenda Ministerstwa Oświaty, poprzez „centralny” zakup całych nakładów nowości wydawniczych, będzie reprezentowała „zorganizowany rynek odbiorców bibliotecznych”, z którym wydawcy będą się liczyć. Tym samym biblioteki będą mogły wpływać za pośrednictwem Zbiornicy zarówno na „rodzaj produkcji wydawniczej, jak i na sposób wydawania książek”. Zob. Cz. Gutry, Centralna Zbiornica..., s. 12. Skalę działalności Zbiornicy obrazują dane ze sprawozdań NDB. Np. Sprawozdanie za miesiąc maj 1946 r. Naczelnego Dyrektora Bibliotek J. Grycza informowało, że „Centralna Zbiornica Książek przyjęła 24391 książek, wysłała 40146 książek", cyt. za: Teki Dokumentacyjne Zakładu Dokumentacji Księgoznawczej Biblioteki Narodowej w Warszawie (dalej cyt. TD ZDK BN), 126. Natomiast dwa lata później wedle Sprawozdania za II kwartał 1948 r. Zbiornica wysłała ogółem 178613 książek do różnych typów bibliotek, zob. AAN, MOśw., NDB, 6728.

Według J. Grycza centralny zakup „wprost u wydawcy dawał [...] oszczędność w postaci 35-40\% rabatu, którą mogliśmy zużywać na dalsze zakupy", zob. J. Grycz, Polska polityka biblioteczna $w$ latach powojennych, [w:] Z zagadnien teorii i praktyki bibliotekarskiej. Studia poświęcone pamięci Józefa Grycza, Wrocław 1961 (dalej cyt. J. Grycz, Polska polityka...), s. 80, 87.

15 J. Grycz, O realizację ustawy bibliotecznej...; tenże, Polska polityka..., s. 86-87.

${ }^{16}$ Oceniając produkcję wydawniczą pod koniec 1947 r. J. Grycz, stwierdził, że jest ona wprawdzie stosunkowo duża, ale nie odpowiada ,istotnym potrzebom czytelnictwa [...] w tych warunkach kompletowanie zbiorów bibliotecznych natrafiło na duże trudności, gdyż z jednej strony brak nam dzieł podstawowych, a z drugiej strony skazani jesteśmy na to, co wydawcy z własnego popędu wydrukowali. Dochodzi do tego jeszcze wzrastająca drożyzna książki [...]. Uzdrowienie tej sytuacji może przynieść jedynie wszechstronny plan wydawniczy", J. Grycz, O realizacje ustawy bibliotecznej... 
oddziaływania. Słowem, dobór i zdobywanie materiału księgowego będą jeszcze przez szereg lat wymagały systematycznego usprawnienia ${ }^{17}$.

Przy czym o ile środowisku bibliotekarskiemu reprezentowanemu przez J. Grycza chodziło o skłonienie wydawców do produkcji rzeczywiście „dobrej” książki, to władzom zależało przede wszystkim na książce użytecznej ideologicznie i politycznie. Od 1949 r. czuwała nad tym Centralna Komisja Wydawnicza, której działalności towarzyszyła likwidacja wydawnictw prywatnych ${ }^{18}$. Natomiast za dobór „odpowiedniej” książki do księgozbiorów bibliotek powszechnych odpowiadała Komisja Oceny Książek powołana w tym samym roku w Ministerstwie Oświaty ${ }^{19}$. Kierowała się ona założeniem, że uzupełnianie księgozbiorów bibliotek powszechnych jest problemem „o charakterze wybitnie politycznym"20.

Nawiasem mówiąc J. Grycz, analizując stan i perspektywy ruchu wydawniczego, zwrócił także uwagę na problem państwowej „gospodarki papierem” twierdząc, że ma ona charakter „niewątpliwie przejściowy, wywołany powojennymi brakami w wytwórczości tego surowca”21. Jednak kontrola nad produkcją i wykorzystaniem papieru odgrywała istotną rolę w polityce władz, również jako jedno z narzędzi regulowania ruchu wydawniczego. Świadczył o tym już dekret PKWN z 7 września 1944 r. o zakresie działania i organizacji Resortu Informacji i Propagandy 22 oraz dekret z 26 kwietnia 1948 r. o gospodarce papierem do druku ${ }^{23}$.

${ }^{17}$ J. Grycz, Polska polityka..., s. 78.

${ }^{18}$ Stanisław A. Kondek, Papierowa rewolucja. Oficjalny obieg ksiażek $w$ Polsce $w$ latach 1948-1955, Warszawa 1999, (dalej cyt. Kondek, Papierowa...), s. 29-38, 54-60.

${ }^{19}$ P. Lechowski, Problemy..., s. 108.

${ }^{20}$ AAN, MOśw., NDB, 6728, J. Skrzypek, Ogólny plan pracy Naczelnej Dyrekcji Bibliotek na okres od dnia 1.IX do 31.XII.50 r.

${ }^{21} \mathrm{~J}$. Grycz, O realizację ustawy bibliotecznej...

${ }^{22}$ Dz.U., 1944, nr 4, poz. 20. Dekret obejmował kontrolą władz zapasy papieru. W 1946 r. z Ministerstwa Informacji i Propagandy wyodrębniono Centralne Biuro Gospodarki Papierem.

${ }^{23}$ Dz.U., 1948, nr 24, poz. 163. Dekret głosił m.in., że użycie do druku „jakiegokolwiek papieru wymaga zezwolenia właściwej władzy” (Art. 2); „Papieru do druku nie wolno nabywać ani zbywać bez zezwolenia właściwej władzy. Zezwolenie na nabycie (przydział) papieru do druku nie zwalnia od obowiązku uzyskania zezwolenia na jego użycie". (Art. 3.); „Każdy posiadacz papieru do druku obowiązany jest przedkładać właściwej władzy wykazy remanentów posiadanego papieru do druku oraz udokumentowane wykazy użycia tego papieru” (Art. 4); „Kto dokonuje obrotu papierem do druku lub go zużywa bez zezwolenia albo wykracza przeciwko innym przepisom niniejszego dekretu oraz rozporządzeń i zarządzeń wydanych na jego podstawie, ulega karze aresztu do 3 miesięcy i grzywny do 300.000 zł albo jednej z tych kar" (Art. 6.). 
Kształtowanie zawartości księgozbiorów bibliotek powszechnych wiązało się oczywiście z problemem ich kontroli i selekcji, w tym z usuwaniem z nich książek ,niepożądanych”. Wydział Cenzury w Resorcie Bezpieczeństwa Publicznego PKWN (RBP-MBP) powstał już na przełomie sierpnia i września $1944 \mathrm{r}$. W jego tworzeniu uczestniczyli funkcjonariusze sowieckiego GŁAWLIT-u ${ }^{24}$, tj. Głównego Urzędu do Spraw Literatury i Wydawnictw ${ }^{25}$. W styczniu 1945 r. szef MBP Stanisław Radkiewicz powołał Centralne Biuro Kontroli Prasy, Publikacji i Widowisk (CBKPPiW) z biurami wojewódzkimi i pełnomocnikami powiatowymi. 15 listopada 1945 r. Tymczasowy Rząd Jedności Narodowej (TRJN) powołał Główny Urząd Kontroli Prasy, Publikacji i Widowisk (GUKPPiW). Został on podporządkowany Prezydium Rady Ministrów. Jego funkcjonowanie potwierdziła dekretem z 5 lipca 1946 r. Krajowa Rada Narodowa (KRN). Zgodnie z art. 2 dekretu Główny Urząd zajmował się m.in. kontrolą rozpowszechniania druków w celu zapobieżenia:

a) godzeniu w ustrój Państwa Polskiego,

b) ujawnianiu tajemnic państwowych,

c) naruszaniu międzynarodowych stosunków Państwa Polskiego,

d) naruszaniu prawa lub dobrych obyczajów,

e) wprowadzaniu w błąd opinii publicznej przez podawanie wiadomości niezgodnych z rzeczywistością ${ }^{26}$.

W praktyce organy GUKPPiW realizowały zalecenia agend Polskiej Partii Robotniczej PPR - potem PZPR (Polskiej Zjednoczonej Partii Robotniczej). Cenzura interesowała się zawartością księgozbiorów bibliotecznych już w 1945 r. Świadczy o tym poufne pismo skierowane 2 października tego roku do kuratorów szkolnych, a podpisane przez Halinę Kuczkowską:

Ministerstwo Oświaty przesyła wykaz książek podlegających niezwłocznemu usunięciu z bibliotek szkolnych wszystkich typów i stopni. Książki wyłączone należy spakować, usunąć z lokalu biblioteki i traktować jako zamknięty inwentarz biblioteczny, pozostawiony do dyspozycji władz szkolnych.

${ }^{24}$ J. Różdżyński, Jak nam Sowieci cenzurę zakładali, „Rzeczpospolita”, ostatnia aktualizacja 07-04-2010 08:38, - http://www.rp.pl/artykul/458182.html?print $=$ tak\&p=0 [12.09.2011]. Zob. też Gtówny Urząd Kontroli Prasy 1944-1949, oprac. D. Nałęcz (Dokumenty do dziejów PRL, z. 6, Warszawa 1994).

${ }^{25}$ Zob. m.in. T. Goban-Klas, Literacki Gutag. Gtawlit, czyli najwyższe stadium cenzury, [w:] Piśmiennictwo - systemy kontroli - obiegi alternatywne, t. 1, pod red. J. Kosteckiego i A. Brodzkiej, Warszawa 1992, s. 46-59.

${ }^{26}$ Dz.U., 1946, nr 34, poz. 210. 
Opracowany przez GUKPPiW wykaz zawierał 30 tytułów. Zarządzenie podkreślało, że kierownicy bibliotek ponoszą osobistą odpowiedzialność za usunięcie tych publikacji z księgozbiorów. Pismo dotyczyło także bibliotek powszechnych:

Jednocześnie proszę [...] Inspektorów Szkolnych o wywarcie swego wpływu, aby i publiczne biblioteki powszechne (powiatowe, miejskie i gminne), pozostające pod opieką Inspektorów Szkolnych, zastosowały się do zarządzenia Ministerstwa i usunęły książki wymienione w załączniku² ${ }^{27}$.

Z cytowanym zarządzeniem wiązała się informacja Józefa Janiczka ówczesnego naczelnika Wydziału Bibliotek w Ministerstwie Oświaty opublikowana w artykule Sprawy biblioteczne w ramach działalności Ministerstwa Oświaty ${ }^{28}$ :

kompletowanie księgozbiorów, odpowiedzialność za dobór książek i pracę wychowawczą biblioteki ponosi bibliotekarz. On, a nie kto inny, odpowiada wobec państwowych władz bibliotecznych, sprawujących z ramienia Ministerstwa Oświaty opiekę i kontrolę nad działalnością bibliotek, za wyniki pracy bibliotecznej w określonym środowisku społecznym. I tylko te władze są uprawnione do kontroli celowości i wartości księgozbioru oraz wydawania oceny co do wyników pracy bibliotekarza i biblioteki. Oczywiście nie dotyczy to książek, propagujących idee faszystowskie, wrogich ustrojowi demokratycznemu, szerzących nienawiść rasową, pornograficznych. Książki te, zgodnie z wykazami Centralnego Biura Kontroli Prasy, Publikacji i Widowisk, muszą być oddane do dyspozycji przedstawicieli powiatowych i wojewódzkich urzędów K.P.P.iW. W sprawie postępowania z tymi książkami, pochodzącymi z bibliotek szkolnych zostały przez Ministerstwo Oświaty wydane odpowiednie zarządzenia ${ }^{29}$.

Informacja J. Janiczka odzwierciedlała stanowisko Ministerstwa Oświaty, które nie godziło się wówczas na nadzorowanie bibliotek „przez jakiekolwiek inne czynniki państwowe, polityczne czy społeczne”, niż władze biblioteczne ${ }^{30}$. NDB (utworzona w marcu 1946 r.) musiała włączyć się zatem w proces „oczyszczania” księgozbiorów. Dlatego wy-

${ }^{27}$ Cyt. za A. Kempa, Literatura źle obecna, „Poradnik Bibliotekarza” 1989, nr 5, s. 28-29.

28 Artykuł został opracowany pod koniec 1945 r., pierwotnie pt. Biblioteki polskie $w$ okresie międzywojennym i po drugiej wojnie światowej. Jego maszynopis znajduje się w materiałach J. Grycza, BN, rps akc. 14927, t. 3, ukazał się zaś pt. Sprawy biblioteczne w ramach dziatalności Ministerstwa Oświaty ("Bibliotekarz", 1946, nr 1-2: styczeń-luty).

${ }^{29}$ J. Janiczek, Sprawy biblioteczne..., s. 11.

30 AAN, MOśw., NDB, 6847, Sprawy biblioteczne w ramach Ministerstwa Oświaty [1945 r.]. 
kazy książek przeznaczonych „do wycofania” z bibliotek były parafowane przez Naczelnego Dyrektora Bibliotek J. Grycza ${ }^{31}$. Systematyczne selekcje druków prowadzono od listopada 1946 r., usuwając ze zbiorów m.in. dzieła autorów uznanych za nieprawomyślnych, emigracyjnych, publikacje o tematyce religijnej, narodowej, kresowej, piłsudczykowskiej, antyrosyjskiej i antykomunistycznej, a także wydawnictwa przedwojenne, zwłaszcza opublikowane na Kresach Wschodnich ${ }^{32}$. W trakcie kolejnych akcji „oczyszczania” bibliotek zauważono, że bibliotekarze nie radzą sobie z ideologiczno-polityczną selekcją książek ${ }^{33}$. Poszerzano więc kolejne wersje wykazów druków „podlegających niezwłocznemu wycofaniu" z księgozbiorów ${ }^{34}$.

Dobór i kontrola księgozbiorów bibliotek powszechnych okazały się jednymi z najważniejszych problemów, z jakimi musiał się zmierzyć J. Grycz wprowadzając w życie zapisy Dekretu o bibliotekach i opiece nad zbiorami historycznymi z 17 kwietnia 1946 r. Zaważyły one na ocenie przez władze zarówno działalności NDB, jak i samego J. Grycza.

\section{Organizacja sieci bibliotek powszechnych}

Realizację Dekretu o bibliotekach... miał wspierać zespół społecznych organów opiniotwórczych i doradczych z Państwową Radą Biblio-

${ }^{31}$ M. Korczyńska-Derkacz, Książki szkodliwe politycznie, czyli akcja „oczyszczania” księgozbiorów bibliotek szkolnych, pedagogicznych i publicznych w latach 1947-1956, [w:] Niewygodne dla wtadzy. Ograniczanie wolności stowa na ziemiach polskich w XIX $i$ XX wie$k u$, pod red. D. Degen i J. Gzelli, Toruń 2010, s. 340.

32 M. Korczyńska-Derkacz, Państwowy Instytut Książki (1946-1949) i jego rola w rozwoju bibliologii, bibliotekarstwa i kultury ksiażki w Polsce, Wrocław 2011, s. 216-217.

${ }^{33}$ Nawet w okresie eskalacji ,papierowej rewolucji” bibliotekarze mieli z tym problem. Jadwiga Filipkowska-Szemplińska w artykule $O$ ksiązkach szkodliwych („Poradnik Bibliotekarza”, 1950, nr 10-11, s. 13-15) stwierdzała, że księgozbiory są ,,jeszcze w wielu wypadkach zaśmiecone książkami pochodzącymi ze zbiórek publicznych, często też posiadają w swoim składzie dzieła przestarzałe, nie odpowiadające dzisiejszym pojęciom i sposobowi myślenia czytelników. Niedobrze jest jeśli książki dostając się do rąk czytelników, zaśmiecają ich wyobraźnię, pobudzają najgorsze instynkty, wywołują zamęt w umysłach i przeszkadzają w zrozumieniu dokonywujących się przeobrażeń społecznych i politycznych”. Dlatego bibliotekarze powinni wiedzieć ,jakiego typu książek nie powinniśmy mieć w swoich księgozbiorach”. Autorka zauważyła też, że „przy całej dobrej woli” bibliotekarze nie mogli sobie poradzić z wyeliminowaniem „książek nieodpowiednich”. Krytykując ich bierność w tym zakresie, radziła: „przecież można wątpliwą książkę zabezpieczyć prowizorycznie odkładając ją na półkę. Później zaś, po odłożeniu w ten sposób kilku książek, zwrócić się do Komitetu Bibliotecznego lub osób, które mógłby służyć pomocą przy ocenie odłożonych książek”. Podobne oczekiwania wobec bibliotekarzy wyrażała rok później J. Skarżyńska w artykule Między nami, „Poradnik Bibliotekarza”, 1951, nr 5.

${ }^{34}$ Zob. AAN, MOśw., NDB, 6979; BN, rps akc. 14927, t. 5; TD ZDK BN, 490. 
teczną na czele ${ }^{35}$. Rady jednak nie powołano, choć NDB przygotowała projekt rozporządzenia w jej sprawie ${ }^{36}$ - być może pod pretekstem, że większość jej kompetencji wchodziło w zakres działania Rady Książki istniejącej od września 1945 roku $^{37}$. Strukturę terenową wspierania „akcji bibliotecznej" miały tworzyć wojewódzkie, powiatowe i gminne komitety biblioteczne ${ }^{38}$, lecz ich organizacja przebiegała opornie. Świadczy o tym m.in. uchwała Rady Państwa z 1 października 1947 r. wzywająca rady narodowe do jak najszybszej organizacji komitetów zgodnie z załączoną instrukcją ${ }^{39}$. Podobne akty pojawiły się jeszcze dwukrotnie na przełomie 1947/48 r. - co dowodzi ich ograniczonej skuteczności. Według Tadeusza Zarzębskiego te komitety, które powstały, nie przejawiały większej aktywności ${ }^{40}$ - brały m.in. udział w „czyszczeniu” księgozbio-

35 Planowane zadania Rady to: „1. badanie potrzeb bibliotekarstwa i czytelnictwa w całym kraju i składanie wniosków w tej sprawie ministrowi oświaty, 2. opiniowanie na zlecenie ministra oświaty projektów ustaw i innych zarządzeń normatywnych ogólnych z zakresu bibliotekarstwa i czytelnictwa, 3. zgłaszanie wniosków ustawodawczych w sprawach bibliotecznych, 4. rozstrzyganie odwołań od decyzyj wojewódzkich komitetów bibliotecznych", cyt. za J. Grycz, Problemy biblioteczne ..., s. 15.

${ }^{36}$ BN, rps akc. 14927, t. 5, Rozporządzenie Ministra Oświaty [...] o Państwowej Radzie Bibliotecznej[...]. Na liście ewentualnych członków Rady znalazło się 40 osób, w tym bibliotekarze, wydawcy, księgarze i literaci. Zob. też J. Grycz, Polska polityka..., s. 71; T. Zarzębski, Uwagi nad życiem Józefa Grycza (W 40. rocznice śmierci), Przegl. Bibliot., 63:1995, z. 1, s. 20.

${ }^{37}$ Do zadań Rady Książki należało m.in. „l) rozważanie i opiniowanie przekazanych jej przez Ministra Oświaty zagadnień i projektów dotyczących: a) wyrównania szkód spowodowanych wojną w zakresie książki i bibliotek, jako też stworzenie podstaw ich odbudowy i dalszego rozwoju. b) ustroju bibliotek [....] oraz ich rozmieszczenia, c) kształcenia fachowych sił bibliotekarskich [....], d) koordynacji interesów twórców, producentów, księgarzy, bibliotek i czytelnictwa, e) planów w zakresie zaspokojenia potrzeb czytelnictwa wszelkiego rodzaju i poziomu, f) propagandy książki i czytelnictwa", zob. J. Grycz, Problemy biblioteczne..., s. 16; J. Muszkowski, Rada Ksiażki, Przegl. Bibliot., 15:1947, z. 3-4, s. 147-155.

NDB planowała nowelizację Dekretu o bibliotekach... w celu określenia wzajemnych relacji między Państwową Radą Biblioteczną a Radą Książki, zob. AAN, MOśw., NDB, 6728, J. Grycz, Plan pracy na II kwartał 1947 r., 10 kwietnia 1947.

${ }^{38}$ AAN, MOśw., NDB, 6847, Projekt organizacji władz i organów bibliotecznych; zob. też J. Grycz, Problemy biblioteczne..., s. 15.

${ }^{39}$ Instrukcja została rozpowszechniona jako okólnik Biura Rad Narodowych Rady Państwa nr 217 z 10 października 1947 r., zob. Organizacja i działalność komitetów bibliotecznych, „Bibliotekarz”, wrzesień-październik 1947, nr 9-10, s. 152-154; Udziat członków ZBiAP w pracy komitetów bibliotecznych, „Bibliotekarz”, lipiec-sierpień 1949, nr 7-8, s. 123-125 (tekst uchwały i instrukcji); zob. też BN, rps akc. 14927, t. 3, materiały „Akcji bibliotecznej”.

${ }^{40}$ T. Zarzębski, Geneza, życie i nauki dekretu, Przegl. Bibliot., 54:1986, z. 3-4, s. 289-290. Kilka lat później, we Wnioskach Komisji do przeprowadzenia analizy pracy Naczelnej Dyrekcji Bibliotek [z 30 marca 1950] zapisano: „Zwrócić uwagę na uaktywnienie komitetów bibliotecznych powołanych ustawą biblioteczną z 1946 r. przy radach narodowych”, AAN. Polska Zjednoczona Partia Robotnicza. Komitet Centralny. Wydział Oświaty (dalej czyt.: Wydz. Ośw. KC PZPR), 237/XVII-231. 
rów ${ }^{41}$. W tej sytuacji trud realizacji Dekretu o bibliotekach... spoczął przede wszystkim na J. Gryczu i J. Janiczku, który pełnił wówczas funkcję naczelnika wydziału bibliotek szkolnych i powszechnych NDB.

Wprowadzając w życie dekret NDB skupiła się, zgodnie z wolą władz zwierzchnich, na organizacji sieci samorządowych bibliotek powszechnych. Pierwsze placówki powstały jeszcze przed uchwaleniem dekretu. Do końca 1945 r. wznowiły bowiem działalność przedwojenne miejskie biblioteki publiczne i część placówek gminnych. Równocześnie tworzono od podstaw sieć biblioteczną na tzw. Ziemiach Odzyskanych ${ }^{42}$. Do 1 stycznia 1946 r. w całym kraju działało 426 bibliotek, dysponujących łącznie ok. $1 \mathrm{mln}$ tomów ${ }^{43}$. Jednocześnie władze nie pozwalały na odtwarzanie sieci bibliotecznych „reakcyjno-klerykalnych” organizacji społecznych ${ }^{44}$.

Po uchwaleniu dekretu w pierwszej kolejności zorganizowano i zaopatrzono w księgozbiory ponad 160 bibliotek powiatowych oraz prze-

${ }^{41}$ Np. 7 i 8 września 1949 r. spalono 124 książki - „nie nadające się do użytku publicznego i nieodpowiadające zagadnieniu dnia dzisiejszego" - z Miejskiej Biblioteki Publicznej w Śmiglu w powiecie kościańskim. Polecenie w tej sprawie wydała komisja w składzie: przewodniczący Powiatowej Rady Narodowej, podinspektor szkolny oraz przewodniczący Powiatowego Komitetu Bibliotecznego. Spalono m.in. Wypisy Juliana Ursyna Niemcewicza, Krzyżaków Henryka Sienkiewicza, powieści Józefa Ignacego Kraszewskiego i Modlitwę Pańska Gabrieli Zapolskiej. Zob. AAN. Wydz. Ośw. KC PZPR, 237/XVII-229, pismo dr Janusza Łopuskiego Kuratora Okręgu Szkolnego Poznańskiego z 18 listopada 1949 r. do Naczelnego Dyrektora Bibliotek Józefa Skrzypka. Na temat roli komitetów bibliotecznych w procesie kontroli i „oczyszczania zbiorów” zob. też J. Filipkowska-Szemplińska, O ksiażkach szkodliwych..., s. 14.

${ }^{42}$ P. Lechowski, Problemy..., s. 97.

43 J. Grycz, Polska polityka..., s. 80.

${ }^{44}$ Do rangi symbolu urasta w tym kontekście rozwiązanie TCL w 1950 r. (pod naciskiem Urzędu Bezpieczeństwa) przez wojewodę poznańskiego Feliksa Widy-Wirskiego. W tym okresie zlikwidowano też wypożyczalnie prywatne, choć jeszcze w 1949 r. J. Janiczek twierdził, że są one „niezbędne dla właściwego rozwoju bibliotekarstwa publicznego, bo choć zaspokajały «niezbyt wybredne upodobania swoich klientów», ale tym samym odciążały biblioteki samorządowe od gromadzenia nadmiernej liczby książek z literatury popularnej”, cyt. za Kondek, Papierowa..., s. 85. Stosunek działaczy partyjnych do tych placówek ukazuje np. Informacja o kontroli księgozbiorów na terenie województwa Opolskiego (z 9 listopada 1950) przesłana do KC PZPR przez Helenę Cesarz, zastępcę kierownika Wydziału Propagandy Oświaty Kultury KW PZPR w Opolu. Pismo informowało, że wycofano 1231 tomów z 1191 bibliotek zawierających łącznie 631821 woluminów. Jednak najwięcej miejsca jego autorka poświęciła prywatnej odpłatnej wypożyczalni książek w Prudniku, ,gdzie większość stanowi beletrystyka kryminalno-sensacyjna, deprawująca młodzież, która z biblioteki powiatowej i bibliotek szkolnych mało korzysta, natomiast chętnie czyta książki z wyżej wymienionej wypożyczalni [....]. Poleciłam K. P. [Komitet Powiatowy PZPR] Prudnik, aby zlikwidowali tę wypożyczalnię, która była doskonałym źródłem dochodu dla prywatnej inicjatywy, a miała tak demoralizujący wpływ na młodzież. K. P. w Prudniku do tej pory polecenia nie wykonał, wobec czego po raz drugi wydałam takie samo polecenie odnośnie likwidacji tej wypożyczalni książek", AAN, Wydz. Ośw. KC PZPR, 237/XVII-229. 
szkolono ich kierowników. Placówki tego typu stanowiły podstawowe ogniwo sieci. Funkcjonowały jako centrale biblioteczne kierujące, nadzorujące i wspomagające biblioteki niższego szczebla: organizacyjnie (także przy zakupie książek), merytorycznie (udzielając instruktażu bibliotecznego) oraz w zakresie poszerzenia oferty książkowej (poprzez „ruchome” komplety książek). Zarządzeniem Ministra Oświaty z 26 lipca 1946 r. ustalono nowe formularze dla bibliotek powiatowych i placówek innych typów ${ }^{45}$. Jesienią 1946 r. wizytator NDB Franciszek Sedlaczek opracowal projekt Statutu Powiatowej Biblioteki Publicznej ${ }^{46}$ oraz Instrukcję dotyczaca organizacji $i$ udostępniania ksieggozbioru... w tych placówkach, opierając się zresztą na projekcie instrukcji z 1939 roku $^{47}$. Resort oświaty pokrywał wynagrodzenia 170 kierowników bibliotek powiatowych. Od 1948 r. finansowanie tych etatów przejął samorząd terytorialny. W miarę możliwości NDB wspierała także zakładanie bibliotek gminnych (miejskich i wiejskich) oraz organizowała szkolenia dla ich pracowników. Zaopatrywano je w książki, określono sposób postępowania $\mathrm{z}$ drukami zbędnymi i dubletami, opracowano również wzorcowy projekt budżetu organów samorządowych dla bibliotek powszechnych ${ }^{48}$. Natomiast $\mathrm{z}$ inicjatywy samorządów powstały pierwsze biblioteki wojewódzkie, m.in. w Warszawie, Wrocławiu i Szczecinie.

Zdarzało się jednak, że oficjalnie uruchomione biblioteki były dopiero w fazie organizacji. Według Kazimierza Witkiewicza do takich placówek należała Publiczna Biblioteka Miasta Krakowa, powołana do życia uchwałą Miejskiej Rady Narodowej w 1945 r. Latem 1947 r. otrzymała ona 100000 zł dotacji od Ministerstwa Oświaty. Zdenerwowany tym, że jego macierzysta Biblioteka Muzeum Przemysłu Artystycznego w Krakowie $^{49}$ nie uzyskała subwencji, K. Witkiewicz informował J. Grycza:

[biblioteka publiczna] faktycznie jeszcze nie istnieje, książki nadsyłane przez Minist[erst]wo i zakupy za pieniądze z subwencji po różnych kątach u nas się tułają. Wiesz dobrze, że powstanie bibl[ioteki] publ[icznej] [...] to jest moje dzieło, które niestety nie $\mathrm{z}$ mojej winy jest martwe $\mathrm{e}^{50}$.

${ }^{45}$ BN, rps akc. 14927, t. 4, Ich opracowanie J. Grycz powierzył 27 kwietnia 1946 r. Związkowi Bibliotekarzy i Archiwistów Polskich (ZBiAP).

${ }^{46}$ BN, rps akc. 14927, t. 2, projekt Statutu Powiatowej Biblioteki Publicznej przedłożony 10 października 1946 r. naczelnikowi J. Janiczkowi przez F. Sedlaczka.

${ }^{47} \mathrm{BN}$, rps akc. 14927, t. 2, Instrukcja dotycząca organizacji i udostępniania księgozbioru powiatowej biblioteki publicznej z 13 listopada 1946 r. z opinią A. Łysakowskiego.

${ }^{48}$ P. Lechowski, Problemy ..., s. 101.

${ }^{49}$ Przed wojenną Miejskie Muzeum Przemysłowe im. Dra A. Baranieckiego.

${ }^{50}$ BN, rps akc. 14966, t. 5, K. Witkiewicz do J. Grycza, 21 lipca 1947. 
Nie dziwi zatem, że do jesieni 1948 r krakowska biblioteka miejska nie nadesłała do Ministerstwa Oświaty sprawozdania ze swojej działalności.

Na działalność NDB miała wpływ sytuacja polityczna. Po sfałszowanych wyborach do Sejmu Ustawodawczego (styczeń 1947 r.) utrwalających władzę komunistów, Stanisław Skrzeszewski ponownie objął stanowisko ministra oświaty, a Józef Grycz i Józef Janiczek zaczęli obawiać się o swoją przyszłość w resorcie. 24 lutego tego roku Edward Kuntze pisał do J. Grycza:

Wyobrażam sobie, że obecny okres przejściowy w Min[isterstwie] i tego wyczekiwania, co będzie, nie jest przyjemny i nie usposabia do pracy [...]. [Witold] Suchodolski zwrócił mi uwagę na artykuł [Żanny] Kormanowej w Trybunie wolności [sic!], w którym zapowiada daleko idące reformy w Min[isterstwie] i w całym szkolnictwie, reformy, które na razie w jej przedstawieniu redukują się do zmian personalnych. Podobno macie dostać nowego wicemin. [Henryka] Jabłońskiego, PPS. Dotychczasowy, p. [H.] Kuczkowska, była zdaje mi się, także PPS. Czy ci wiceministrowie mają w ogóle coś do gadania, czy są tylko na to, aby dyrektorom dep[atramentów], Panu, Suchodolskiemu [...] utrudniać pracę [...]. Ma Pan kłopoty w Min[isterstwie], mam i ja swoje w Bibl[iotece Jagiellońskiej] ${ }^{51}$.

Pod koniec marca E. Kuntze życzył J. Gryczowi, aby sprawy w resorcie ,jakoś spokojnie rozwikłały się. Może jeszcze Święta będzie Pan miał spokojne" 52 . Zamieszanie w ministerstwie skończyło się tym, że J. Grycz i J. Janiczek zachowali swoje stanowiska. Jednak mimo przychylności dla NDB deklarowanej przez wiceministra H. Jabłońskiego - „kto go tam wie" komentował J. Janiczek ${ }^{53}$ - pozycja Dyrekcji w Ministerstwie Oświaty ulegała w kolejnych miesiącach stopniowemu osłabieniu. Dyrekcji brakowało pracowników; J. Grycz narzekał też na złe warunki lokalowe, w jakich musieli pracować urzędnicy NDB. Co gorsza Dyrekcji przyznano na 1947 r. mniejszy udział w budżecie Ministerstwa Oświaty, niż w roku poprzednim ${ }^{54}$, tj. $77 \mathrm{mln}$ zł - o ponad $51 \mathrm{mln}$ zł mniej niż NDB

${ }^{51}$ Tamże, t. 3b, E. Kuntze do J. Grycza, 24 lutego 1947.

52 Tamże, E. Kuntze do J. Grycza, 29 marca 1947. Po proteście E. Kuntzego przeciw mianowaniu Ksawerego Świerkowskiego na jego zastępcę w BJ (Tamże, E. Kuntze do J. Grycza, 28 kwietnia 1947) oraz po liście z maja tego roku, w którym E. Kuntze informował J. Grycza, że „nie ma nic przeciw emeryturze” regularna do tej pory korespondencja między nimi prawie się urywa (w spuściźnie J. Grycza). E. Kuntze był już wtedy ciężko chory.

53 Tamże, t. 3, J. Janiczek do J. Grycza, 6 sierpnia 1947.

${ }^{54}$ Kwoty przyznane na akcję biblioteczną wyniosły „w r. 1944 zł 195.000, w r. 1945 zł 8 mil., w r. 1946 zł 26 mil”, J. Grycz, O realizację ustawy bibliotecznej... Zob. też: BN, rps akc. 14927, t. 3, J. Grycz, Budżet bibliotek [na r. 1947]; AAN, MOśw., NDB, 6728, J. Grycz, Plan pracy na II kwartał 1947 r., 10 kwietnia 1947. 
potrzebowała ${ }^{55}$. O pewnej stagnacji w działalności Dyrekcji świadczy np. to, że wspomniana wyżej instrukcja dla bibliotek powiatowych została formalnie wprowadzona $\mathrm{w}$ życie prawie po roku od jej opracowania rozporządzeniem ministra oświaty z lipca $1947 \mathrm{roku}^{56}$. Mimo trudności zakończono jednak budowę pierwszego, podstawowego szczebla sieci, organizując do końca tego roku ponad 260 bibliotek powiatowych.

Widoczny brak znaczącego postępu w organizacji bibliotek gminnych wynikał z różnych przyczyn. Najważniejszą była mała aktywność samorządów w tym zakresie, głównie spowodowana brakiem środków finansowych $^{57}$. Dotyczyło to zwłaszcza gmin wiejskich, które często nie uwzględniały w swoich budżetach wydatków na biblioteki ${ }^{58}$. W reakcji na ten stan rzeczy minister administracji publicznej Edward OsóbkaMorawski skierował 19 kwietnia 1947 r. okólnik do wojewodów i prezydentów miast wydzielonych w sprawie realizacji przepisów Dekretu o bibliotekach..., zawierający m.in. żądanie przedstawienia sprawozdań $\mathrm{z}$,akcji bibliotecznej”. Sprawa ta niepokoiła również środowisko bibliotekarskie. 22 kwietnia Zarząd Główny Związku Bibliotekarzy i Archiwistów Polskich (ZBiAP) wystąpił z apelem do „wszystkich czynników państwowych" o poparcie

akcji bibliotecznej przez wydatniejszą niż dotychczas pomoc finansową a w szczególności przez przyznanie odpowiednich kredytów na wydatki zwyczajne bibliotek w budżecie na rok 1947 jak również w trzechletnim planie inwestycyjnym ${ }^{59}$.

Problem zbyt małej liczby placówek gminnych oraz niezadowalającej wielkości i zawartości ich księgozbiorów podnoszony był również w pra$\mathrm{sie}^{60}$. W samym Ministerstwie Oświaty skrytykowano działalność NDB

${ }^{55}$ BN, rps akc. 14927, t. 3, J. Grycz, Budżet bibliotek [na r. 1947].

${ }^{56}$ Zarzadzenie Ministra Oświaty z dnia 24 lipca 1947 r. w sprawie instrukcji dotyczacej organizacji i udostepniania ksiegozbioru powiatowej biblioteki publicznej. „Dz. Urz. Min. Ośw.”, 1947, nr 9, poz. 226.

57 T. Zarzębski, Geneza ..., s. 289. Dlatego istotnym wsparciem dla „akcji bibliotecznej" stały się społeczne zbiórki (organizowane od 1945 r.) datków pieniężnych przeznaczonych na biblioteki powszechne. Np. w 1946 r. zebrano w ten sposób 29 mln zł. Budżet „akcji bibliotecznej” zasilały również okolicznościowe dotacje różnych organów administracji państwowej, zob. P. Lechowski, Problemy..., s. 102.

58 Tamże, s. 101.

${ }^{59}$ BN, rps akc. 14927, t. 5. Zob. też Wnioski uchwalone na Zebraniu Delegatów Kót Z.B.iA.P. $w$ dniach 11-12 maja 1947 r., „Bibliotekarz”, 1947, nr 5-6, s. 102.

${ }^{60}$ J. Grycz zachował m.in. artykuł Ludmiły Protschke Gtód ksiązki?, „Odrodzenie”, 22 lutego 1948, nr 8(169), s. 6. Musiał wywołać w NDB wrażenie, o czym świadczą liczne podkreślenia w jego tekście. Autorka stwierdzała m.in., że „realizacja ustawy bibliotecznej nie przyniosła spodziewanych zmian na rynku wydawniczym - jej rozmiary były bar- 
w czasie konferencji dyrektorów departamentów (12 czerwca 1947 r.), wytykając jej szereg „błędów i braki praktyczne”. Zwrócono m.in. uwagę na to, że „akcja biblioteczna” często prowadzona jest chaotycznie, a sieć bibliotek organizowana jest „przypadkowo - nie jest sprawnie zarządzana" ${ }^{61}$. Zarzucono też Dyrekcji zaniedbania w zakresie oceny książek (m.in. pochodzących z darów) i ich doboru do księgozbiorów bibliotek powszechnych. W ocenie kierownictwa resortu NDB nie radziła sobie z tym zdaniem. Dlatego dyrektor gabinetu ministra Józef Barbag radził, aby dodatkowo „stworzyć komisję oceny wydawnictw z punktu widzenia państwowego i politycznego", która wspomogłaby Dyrekcję ${ }^{62}$.

dzo szczupłe, odbudowa dawnych bibliotek i zakładanie nowych ledwo się zaczęły". W bibliotekach publicznych „powiatowych i gminnych sieci brak «dobrej literatury pięknej» [...] nie znajdzie się jej nawet 500 tytułów". Placówek jest za mało, zwłaszcza na wsi. Brakuje w nich książek, a na półkach stoją wydawnictwa „po które nikt nie przychodzi”. Także w „Bibliotekarzu” pojawił się artykuł o znamiennym tytule Od stów do czynu, 1947, nr 5/6, s. 77-79, w którym stwierdzono, że w rok po ogłoszeniu Dekretu o bibliotekach... jego przepisy okazały się tylko postulatami. Zob. też Realizacja Dekretu o bibliotekach i opiece nad zbiorami bibliotecznymi (Przeglad czasopism za rok 1947), „Bibliotekarz”, 1948, nr 1-2, s. 26-27.

W reakcji na krytykę prasową J. Grycz wyjaśniał, że dekret „ukazał się w okresie i warunkach niesprzyjających. Okres to odbudowy powojennej na wszystkich odcinkach życia wymagającej olbrzymich środków finansowych, co stworzyło konieczność hierarchizacji potrzeb i ustalenia kolejności ich zaspokojenia. W ogólnym planie potrzeby kulturalne, a między nimi i biblioteczne, nie mogły być wysunięte na czoło. Rozporządzalne fundusze musiały być przeznaczone na inne, pilniejsze odcinki odbudowy”. Drugą przeszkodę stanowił brak „wystarczających źródeł dochodowych związków samorządowych” na zakładanie i utrzymywanie bibliotek, zob. J. Grycz, O realizację ustawy bibliotecznej...

${ }^{61} \mathrm{BN}$, rps akc. 14927 , t. 4.

62 Taką komisję powołano w 1949 r., już po usunięciu J. Grycza z NDB, ale jej działalność nie poprawiła oceny Dyrekcji. Podczas narady zorganizowanej 28 grudnia 1949 r. z inicjatywy Wydziału Oświaty KC PZPR stwierdzono m.in., że: „Księgozbiory. Duża przewaga literatury pięknej na niekorzyść popularno-naukowej. Wciąż za mały stosunek literatury marksistowskiej i społeczno-gospodarczej. Dobór książek bezplanowy. Możnaby przecież zaplanować pewne pozycje w skali rocznej przewidując uroczystości, rocznice jak np. rocznica urodzin Stalina, Wielka Socjal. Rewolucja itp. Komisja ocen [NDB] nie prowadziła pracy w należytym kierunku. Recenzenci nieodpowiedni [....]. Recenzje mdłe bez naświetlenia politycznego Społecznego [sic!] i gospodarczego. Ograniczały się na ogół do podania treści. Szereg książek nabywano u wydawców prywatnych [....]. Forsowano gwałtownie Kraszewskiego ze względu na poczytność i rentowność wydawców, nie kierując się momentami ideologicznymi”. Wydawców prywatnych oceniono jako „nieodpowiednie źródło zakupów" książek dla bibliotek publicznych. Zob. AAN, Wydz. Ośw. KC PZPR, 237/XVII-228, Biblioteki i Czytelnictwo, 27.I.1949-22.II.1952,

Podobne zarzuty zawierał Protokót Nr. 5 z posiedzenia Komisji do przeprowadzenia analizy pracy Naczelnej Dyrekcji Bibliotek. Posiedzenie odbyło się 20 marca 1950 r. Odnośnie pracy Komisji Ocen i Doboru Wydziału Księgarsko-Wydawniczego NDB stwierdzono m.in., że „ewidencja książek świeżo wydanych ich ocena, a zatem możność szybkiego rozprowadzenia jest od początku źle postawiona. Szwankowała pod kierownictwem tow. Żolątkowskiej, nie poprawil się stan pod kierownictwem tow. Szemplińskiej [....]. Szwankuje 
Do krytyki przebiegu „akcji bibliotecznej” dołączył także Sejm Ustawodawczy, który przecież wcześniej zaakceptował zbyt małe środki budżetowe przeznaczone na potrzeby bibliotekarstwa ${ }^{63} .3$ lipca posłowie uchwalili rezolucję wzywającą rząd „do przyspieszenia prac nad realizacją ustawy bibliotecznej"64. Takie wystąpienie rzutowało negatywnie na ocenę pracy NDB i jej kierownictwa. Przygnębiony J. Janiczek pisał 6 sierpnia do przebywającego poza Warszawą J. Grycza:

czekam na powrót Skrzeszewskiego. Muszę się z nim definitywnie rozmówić. Albo, albo. Dłużej się męczyć w tej zgniłej atmosferze nie zamierzam. Wydaje mi się, że w Polsce pracy dla ludzi chętnych nie zabraknie. Jestem za stary na to by mi władza imponowała" 65 .

Również dla schorowanego J. Grycza był to zły okres. W opinii Mariana Łodyńskiego Naczelny Dyrektor Bibliotek popadł w „stan marazmu”, „dziwnego indyferentyzmu czy laisser-faire’izmu”66.

również przygotowywanie spisów książek do wycofania. Spisy te opracowywane na podstawie materiałów z terenu (selekcję przeprowadzono w 1949 r.) sporządzane są nieporządnie tak pod względem bibliograficznym i merytorycznym. Sporządzone do tej pory dwie listy książek zastrzeżonych (ok. 600 poz.) po uzgodnieniu z Urzędem Kontroli Prasy są u tow. Iwańczaka. Wydział nie potrafił uporać się ze spisami nadesłanymi przez biblioteki szkolne [....]. Niezałatwienie tej sprawy było powodem ostrego monitu pod adresem N.D.B. ze strony Ministerstwa Oświaty. Za wymienione wyżej wymagania odpowiedzialność ponosi w pełni zespół pracowników Wydziału. Tow. Szemplińska jest bibliotekarką, nie rozumie i nie zna pracy organizacyjnej [....]. Zdaniem Komisji, Wydział mający obok Wydziału bibliotek powszechnych najważniejsze zadania pracuje źle i niewłaściwie. Wydział musi dostać dobrego organizatora, który potrafi ustawić właściwie pracę. Należy rozpatrzyć możliwość współpracy w zakresie ocen z Urzędem Kontroli Prasy”. Zob. AAN, Wydz. Ośw. KC PZPR, 237/XVII-231, Protokół nr 5 z posiedzenia Komisji do przeprowadzenia analizy pracy Naczelnej Dyrekcji Bibliotek. W efekcie J. Filipkowska-Szemplińska złożyła rezygnację z kierownictwa Wydziału Księgarsko-Wydawniczego NDB (pełniła je od października 1949 r.) i została przeniesiona do Wydziału Bibliotek Naukowych NDB.

Nb. przewodnicząca Komisji Oceny i Doboru usprawiedliwiała się tym, że: „Zagadnienie wycofania książek i sporządzania list książek zastrzeżonych i niewskazanych natrafia [....] na poważne trudności spowodowane nieustaleniem i płynnością kryteriów jakimi przy tej pracy należy się kierować”, cyt. za AAN, Wydz. Ośw. KC PZPR, 237/XVII-231, Sprawozdanie Komisji do przeprowadzenia analizy pracy Naczelnej Dyrekcji Bibliotek, [30 marca 1950].

${ }^{63}$ Kondek, Papierowa..., s. 86.

${ }^{64}$ T. Zarzębski, Geneza..., s. 288.

${ }^{65}$ BN, rps akc. 14966, t. 3, J. Janiczek do J. Grycza, 6 sierpnia 1947.

${ }^{66}$ M. Łodyński wyrażał w tym kontekście żal, że A. Łysakowski nie został w „swoim czasie" Naczelnym Dyrektorem Bibliotek, zob. M. Łodyński do A. Łysakowskiego, 8 listopada 1947, [w:] Bibliotekarstwo polskie 1925-1951 w świetle korespondencji jego wspóttwórców, wyboru z listów Adama Łysakowskiego, Mariana Łodyńskiego, Józefa Grycza i Heleny Hleb-Koszańskiej dokonała, wstępami, przypisami i indeksem opatrzyła M. Dembowska, Warszawa 1995, (dalej cyt.: Bibliotekarstwo polskie...) s. 284. 
„Akcja biblioteczna” zintensyfikowała się po przemówieniu radiowym Bolesława Bieruta z 16 listopada 1947 r. na temat upowszechnienia kultury. Stwierdził w nim m.in., że książka powinna być „tania, dobra i dostępna dla najszerszych mas"67. Powszechny dostęp do książki powinny zapewnić samorządowe biblioteki publiczne. Już 27 listopada J. Grycz informował A. Łysakowskiego, że NDB walczy o 1 miliard zł na realizację dekretu i „mamy nadzieję, że go uzyskamy”. Równocześnie wyrażał obawę, iż „będzie kłopot z wydatkowaniem takiej sumy" ${ }^{68}$. To stwierdzenie dziwi, ponieważ J. Grycz stale podkreślał niedobór środków finansowych przeznaczanych na biblioteki. Co więcej, w przygotowanym kilka tygodni później artykule $O$ realizacje ustawy bibliotecznej... podkreślił, że na realizację ,akcji bibliotecznej potrzebne jest ok. 1 miliarda zł rocznie przez 5 lat”. Perspektywa przyspieszenia prac nad rozbudową sieci bibliotek publicznych wcale nie poprawiła jego samopoczucia. W cytowanym liście do A. Łysakowskiego pisał:

Najgorzej, że czuję się fatalnie, leczenie odnosi małe skutki, trzeba by koniecznie wypocząć i wyjechać na 3-4 tygodnie, a tu pracy powyżej uszu. Wszystkiemu winne fatalne warunki w M[inisters]twie, brak ludzi i brak zrozumienia naszych potrzeb. Naprawdę trudno wytrzymać, nie ma to, jak pracować spokojnie w jakiejś bibliotece! ${ }^{69}$

J. Grycz nie mógł pozwolić sobie na odpoczynek. Po przemówieniu B. Bieruta resort oświaty musiał wykazać się postępem w budowie sieci bibliotecznej. Zapewne dlatego już 21 grudnia przeprowadzono $w$ Nagłowicach akcję „równoczesnego i uroczystego" uruchomienia pełnej sieci 237 bibliotek gminnych w województwie kieleckim ${ }^{70}$. Ogółem pod koniec 1947 r. w całym kraju funkcjonowało ponad 900 samorządowych bibliotek powszechnych z blisko 3 mln tomów ${ }^{71}$, w tym 264 powiatowe i 700 gminnych (446 w gminach wiejskich) ${ }^{72}$. J. Grycz przyznawał jednak, że

${ }^{67}$ Cyt. za M. Korczyńska-Derkacz, Książki szkodliwe..., s. 337; B. Bierut, O upowszechnienie kultury, Warszawa 1948.

${ }^{68}$ BN, rps 10540, k. 127, J. Grycz do A. Kysakowskiego, 27 listopada 1947, w: Korespondencja A. Łysakowskiego, T. IV: Gr-Gu [dalej cyt.: Korespondencja A. Łysakowskiego...].

${ }^{69}$ Przygnębienie J. Grycza wynikało też z przeświadczenia, że ktoś mu w ministerstwie „szyje buty!”, tamże, k. 126. Zob. też BN, rps akc. 14966, t. 3b, E. Kuntze do J. Grycza, 10 grudnia1947.

70 T. Zarzębski, Geneza..., s. 289-290.

${ }^{71}$ J. Grycz, Polska polityka..., s. 80.

72 J. Janiczek, Stan liczbowy i perspektywy rozwojowe bibliotek $w$ Polsce na podstawie rejestracji z 1948 r., Przegl. Bibliot., 16:1948, z. 3-4, s. 154. 
daleko jeszcze do osiągnięcia przedwojennej liczby posiadanych [przez biblioteki samorządowe] książek. Po tym względem czeka nas olbrzymi wysiłek, a będzie on musiał być jeszcze większy, gdy podejmiemy akcję uzupełniania sieci bibliotecznej przez powołanie do życia dalszych [...] bibliotek $^{73}$.

W styczniu 1948 r. M. Łodyński oceniał, że J. Grycz jako Naczelny Dyrektor Bibliotek „leży i zresztą sam się kładzie”, i przewidywał: „doprawdy smutno przedstawia mi się nasza przyszłość u końca powojennej piatiletki"74 - mimo, że rok zapowiadał się jako przełomowy dla ,akcji bibliotecznej"75. Przede wszystkim o 90\% wzrosła dotacja Ministerstwa Oświaty dla bibliotek samorządowych - do $138 \mathrm{mln}$ zł, ale był to ciągle niewystarczający budżet. Został w większości przeznaczony na centralny zakup książek dla bibliotek ${ }^{76}$. Tymczasem sprawą sieci bibliotek powszechnych zainteresował się sam B. Bierut ${ }^{77}$. Władze komunistyczne konsekwentnie dążyły bowiem do uczynienia z bibliotekarstwa jednego z głównych narzędzi indoktrynacji społeczeństwa. 5 marca 1948 r. Rada Państwa przyjęła uchwałę w sprawie upowszechniania książki i czytelnictwa w Polsce. Zobowiązywała organy państwowe i samorządowe do podjęcia:

szerokiej akcji dla upowszechnienia książki i czytelnictwa opartej na następujących wytycznych:

1) Opracowanie planu wydawniczego oraz stworzenia warunków dla jego wykonywania.

2) Zapewnienie masowemu czytelnikowi dostępu do książki zarówno w formie wypożyczenia, jak i jej nabycia przez:

a) przełamanie drożyzny książki,

b) zorganizowanie masowej akcji społecznej propagandy książki, tworzenie kół czytelniczych itp.,

c) przystąpienie do realizacji wytycznych ustawy bibliotecznej w zakresie stworzenia sieci bibliotecznej,

d) $[\ldots]$ ułatwienia nieprzygotowanemu czytelnikowi otrzymanie książki wartościowej, książki budzącej zamiłowanie do czytania, a ponadto wychowawczej i kształcącej ${ }^{78}$.

Uchwała była swoistym votum nieufności wobec władz bibliotecznych, które przecież w miarę możliwości starały się realizować zapisy

${ }^{73} \mathrm{~J}$. Grycz, O realizacje ustawy bibliotecznej...

${ }^{74}$ M. Łodyński do A. Łysakowskiego, 23 stycznia 1948, [w:] Bibliotekarstwo polskie..., s. 287.

75 J. Grycz, Polska polityka..., s. 80.

${ }^{76}$ P. Lechowski, Problemy..., s. 101.

${ }_{77}$ M. Korczyńska-Derkacz, Państwowy Instytut..., s. 233.

${ }^{78}$ Uchwała Rady Państwa w sprawie upowszechniania książi i czytelnictwa w Polsce, „Bibliotekarz”, marzec 1948, nr 3, s. 33-34. 
Dekretu o bibliotekach... ${ }^{79}$. Na jej podstawie powołano kilka dni później Komitet Upowszechnienia Książki (KUK). Był to w istocie organ partyjny, który dublując funkcje NDB spowodował, że Dyrekcja utraciła centralne kierownictwo nad „akcją biblioteczną" ${ }^{\circ 0}$. KUK przejął bowiem zadanie organizacji sieci bibliotek samorządowych, przede wszystkim gminnych (wiejskich i małomiasteczkowych). Potwierdził to sam J. Janiczek w artykule opublikowanym w sierpniu tego roku:

Rzeczywisty przełom [...] został dokonany w wyniku uchwały Rady Państwa z marca roku bieżącego o powstaniu Komitetu Upowszechniania Książki. Projektowana zespolonym wysiłkiem Komitetu Upowszechniania Książki oraz samorządu terytorialnego przy fachowej współpracy Ministerstwa Oświaty sieć biblioteczna składająca się z punktów bibliotecznych, oraz bibliotek w gminach miejskich i wiejskich, miastach powiatowych i wojewódzkich - zapewni każdemu obywatelowi łatwy dostęp do potrzebnej mu książki dla rozrywki, w pracy zawodowej lub samokształceniowej ${ }^{81}$.

W ten sposób NDB stała się wykonawcą decyzji partyjnych w zakresie zakładania i wyposażania bibliotek powszechnych.

21 lipca Kancelaria Rady Państwa wydała Okólnik nr 54 [....] w sprawie organizacji bibliotek gminnych. Dokument czynił prezydia wojewódzkich rad narodowych odpowiedzialnymi za realizację ,akcji bibliotecznej”. Określał też powinności w tym zakresie gminnych i powiatowych rad narodowych. Zobowiązywał je do wyposażenia i utrzymania odpowiedniego lokalu bibliotecznego oraz do wyszukania kandydata na kierownika biblioteki gminnej ,posiadającego odpowiednie wyrobienie społeczne, należyte nastawienie ideowe" i sfinansowania jego wynagrodzenia $^{82}$. Nad tym, by w księgozbiorach bibliotecznych znalazły się książki „wartościowe ideologicznie” miała czuwać Komisja Główna do Spraw Kultury powołana w lipcu przy Radzie Ministrów. Obok ministrów

${ }^{79}$ W wykreślonym fragmencie rękopisu (z 6 października 1948 r.) artykułu Obecny etap akcji bibliotecznej J. Grycz bronił NDB wyjaśniając, że „akcja biblioteczna [...] prowadzona była i jest planowo i systematycznie [...] warunki i środki do tego potrzebne musiały być stopniowo wywalczane, od nich uzależnione było postępowanie czynników prowadzących akcję. Wyniki i tempo ich osiągania to wypadkowa wielu różnorodnych warunków i wysiłków”. Zob. BN, rps akc. 14927, t. 3. Artykuł ukazał się na łamach „Rady Narodowej" 1 listopada 1948, nr 21(135), s. 10-12.

${ }^{80}$ Kondek, Papierowa..., s. 91.

${ }^{81}$ J. Janiczek, Sieć bibliotek gminnych, „Rada Narodowa” 1948, nr 15-16 (129-130), s. 4.

82 Cyt. za „Biuletyn Służbowy Dolnośląskiej Wojewódzkiej Rady Narodowej”, 1948, $\mathrm{nr} 8$, s. 14. W listopadzie tego roku ukazał się stosowny okólnik w sprawie punktów bibliotecznych, zob. T. Zarzębski, Geneza..., s. 289. 
oświaty, kultury i sztuki w jej skład weszli przedstawiciele kontrolowanych przez władze organizacji społecznych ${ }^{83}$.

Ustawa skarbowa przydzieliła Ministerstwu Oświaty na „akcję biblioteczną" w 1949 r. ponad 444 mln zł, a KUK aż 350 mln. Budżet Komitetu miał być wykorzystany m.in. do:

- utworzenia 20 tys. punktów bibliotecznych według projektu opracowanego przez $\mathrm{NDB}^{84}$;

- powiększenia krajowej sieci bibliotek powszechnych do 5 tys. placówek. Przy czym, według danych NDB, w sierpniu-wrześniu 1948 r. istniały 2573 biblioteki, w tym 2300 gminnych $^{85}$;

- uzupełnienia księgozbiorów bibliotek powszechnych do $4 \mathrm{mln}$ tomów ${ }^{86}$. Według szacunku NDB w sierpniu-wrześniu 1948 r. liczyły już 3,8 mln woluminów ${ }^{87}$.

Wymienione zadania postanowiono wykonać jeszcze w 1948 roku $^{88}$. Taką decyzję podjął KUK dzięki „poparciu moralnemu i finansowemu" Komisji Głównej do Spraw Kultury ${ }^{89}$. Na jej realizację przeznaczono $300 \mathrm{mln}$ zł z funduszu Państwowego Planu Inwestycyjnego ${ }^{90}$ i $80 \mathrm{mln}$ zł pozyskanych przez NDB na urządzenia biblioteczne ${ }^{91}$. Wykonaniem zajęła się NDB organizując od września 1948 do połowy stycznia 1949 r. nowe punkty biblioteczne, które otrzymały komplety książek z bibliotek gminnych i powiatowych. Założono też 1600 nowych bibliotek gminnych. J. Grycz odnotował, że zaopatrzono je w centralnie zakupione komplety $500 \mathrm{książek}^{92}$. W rzeczywistości według Stanisława A. Kondka organizatorom akcji „udało się zgromadzić tylko ok. 450 tytułów; do większości bibliotek gminnych dotarło ich jeszcze mniej" 93 . Książki dobrała specjalna komisja powołana w Mini-

83 J. Grycz, Polska polityka..., s. 81. Zob. też Uchwała Rady Ministrów o utworzeniu Komisji Gtównej do Spraw Kultury z dnia 27 lipca 1948 r., „Biuletyn Informacyjny Komisji Głównej do Spraw Kultury", 1949, nr 1, s. 3.

84 AAN, MOśw., NDB, 6728, J. Grycz, Sprawozdanie za II kwartał 1948 r.

${ }^{85} \mathrm{BN}$, rps akc. 14927, t. 3, Dane o krajowej sieci bibliotek powszechnych organizowanych na podstawie dekretu o bibliotekach z czerwca [sic!] $1946 \mathrm{r}$.

${ }^{86}$ Kondek, Papierowa..., s. 91.

${ }^{87} \mathrm{BN}$, rps akc. 14927 , t. 3, Dane o krajowej sieci bibliotek...

88 J. Janiczek do J. Grycza, 11 sierpnia 1948, BN, rps akc. 14966, t. 3.

89 J. Grycz, Polska polityka..., s. 81.

${ }^{90}$ BN, rps akc. 14927, t. 3, J. Grycz, Akcja biblioteczna, 27 października 1948.

91 Ogółem NDB uzyskała kwotę „,380 mil. zl, z czego 80 mil. na urządzenia biblioteczne i 300 mil. na założenie nowych bibliotek gminnych. Dzięki temu sukursowi mogliśmy przygotować powołanie do życia 1600 nowych bibliotek gminnych", J. Grycz, Polska polityka..., s. 81.

92 Tamże.

${ }^{93}$ Kondek, Papierowa ..., s. 91. 
sterstwie Oświaty ${ }^{94}$. W kompletach znalazły się oczywiście m.in. wydawnictwa propagujące ideologię komunistyczną ${ }^{95}$. Placówkom dostarczono też pomoce, w tym księgi inwentarzowe, drukowane karty katalogowe oraz instrukcję dla kierowników bibliotek i punktów bibliotecznych (wydaną w 25 tys. egz.) ${ }^{96}$. W ciągu kilku tygodni przeszkolono 1800 kandydatów na bibliotekarzy gminnych i 18 tys. przyszłych kierowników punktów bibliotecznych ${ }^{97}$.

Oficjalne uruchomienie nowych placówek zaplanowano na 19 grudnia 1948 r. J. Janiczek informując o tym J. Grycza wspomniał o spodziewanym połączeniu się PPR i PPS ${ }^{98}$. I to właśnie ze względu na termin Kongresu Zjednoczeniowego (15-21 grudnia) przesunięto na 16 stycznia 1949 r. centralną uroczystość otwarcia sieci. J. Janiczek stwierdził potem, że wyszło to „dla samej sprawy na dobre, gdyż wykończono wiele takich prac, jakich nie zdołałoby żadną miarą wykończyć wcześniej"99. Uroczystość równoczesnego otwarcia nowych bibliotek odbyła się we wsi Pustelnik, w obecności mediów i przedstawicieli władz centralnych. Wziął w niej udział J. Grycz ${ }^{100}$, natomiast J. Janiczek uczestniczył w otwarciu sieci w województwie szczecińskim ${ }^{101}$. Według T. Zarzębskiego dokonano tym samym „iście bibliotekarskiego cudu”, przy czym „,zarówno całość, jak i wszystkie poszczególne placówki w niczym nie przypominały Patiomkinowskich atrap"102. Cytowana opinia budzi wątpliwości, bowiem przebieg owego „cudu” i jego rezultaty wymagają jeszcze dokładnego zbadania. Na przykład Piotr Lechowski słusznie zwraca uwagę na to, że w sytuacji braków w wyposażeniu oraz trudnych warunków lokalowych, kadrowych i finansowych wiele wiejskich bibliotek gminnych istniało „tylko formalnie”. Zwłaszcza, że ich księgozbiory

94 J. Grycz, Polska polityka..., s. 81.

95 Zob. Wykaz książek nr 1 zakupionych z kredytu Planu Inwestycyjnego z roku 1949 i przydzielonych przez Ministerstwo Oświaty Gminnej Bibliotece Publicznej w ramach zorganizowanej akcji rozbudowy krajowej sieci bibliotecznej [...], cyt. za: Kondek, Papierowa..., s. 90-91.

${ }^{96}$ J. Grycz, Polska polityka..., s. 81.

97 T. Zarzębski, Geneza..., s. 290.

98 BN, rps akc. 14966, t. 3, J. Janiczek do J. Grycza, 11 sierpnia 1948.

${ }_{99} \mathrm{~J}$. Janiczek, Nowy etap w pracach nad upowszechnieniem ksiazki. Na marginesie akcji organizacji bibliotek gminnych i punktów bibliotecznych, „Bibliotekarz”, styczeń-luty 1949, nr 1-2, s. 11.

100 T. Zarzębski, Geneza..., s. 290.

101 AAN, Wydz. Ośw. KC PZPR, 237/XVII-228, Biblioteki i Czytelnictwo, 27.I.1949-22.II.1952, Pismo Henryka Dąbrowicza wiceprzewodniczącego Prezydium Wojewódzkiej Rady Narodowej w Szczecinie do Kancelarii Rady Państwa w Warszawie, 21 stycznia 1949 r.

102 T. Zarzębski, Uwagi nad życiem Józefa Grycza..., s. 22. 
często nie były w całości opracowane, a do tego szybko niszczały ${ }^{103}$. Ponadto źródła podają różne liczby bibliotek samorządowych funkcjonujących na przełomie 1948/49 r. Na przykład dokument z grudnia 1949 stwierdzał, że pod koniec 1948 r. działało 2761 placówek ${ }^{104}$. Według Zofii Żołątkowskiej z NDB w lutym 1949 r. istniało ok. 2300 bibliotek $^{105}$.

Uroczystość w Pustelniku nie kończyła budowy sieci bibliotek powszechnych ${ }^{106}$, która docelowo miała składać się z: (a) 14 bibliotek wojewódzkich, (b) 269 bibliotek powiatowych, (c) 3001 bibliotek gmin. wiejskich, (d) 700 bibliotek miejskich ${ }^{107}$.

W notatce skierowanej do wiceministra H. Jabłońskiego, sporządzonej 27 października 1948 r., J. Grycz zwracał uwagę na to, że:

Do usunięcia pozostały jeszcze trudności: 1) budżetowe [...] 2) [...] brak odpowiednich książek dla masowego czytelnika. Obecnie nie liczą się z poziomem i zainteresowaniami czytelnika prymitywnego, dla którego i grafika książki musi być specjalnie przystosowana. Plan wydawniczy musi tu zwrócić szczególną uwagę. 3) Potrzeba też, aby związki samorządowe uwzględnity większe niż dotychczas świadczenia na rzecz bibliotek powszechnych, do czego są zobowiązane dekretem. 4) Postulat scalenia akcji bibliotecznej prowadzonej przez organizacje społeczne, oświatowe, młodzieżowe, związki zawodowe, partie polityczne itp. i skoordynowanie jej z akcją prowadzoną przez państwo i samorząd ${ }^{108}$.

Uważał też za konieczne stworzenie systemu szkolenia bibliotekarskiego w połączeniu z ustaleniem wymaganych kwalifikacji dla poszczególnych typów „pracowników bibliotecznych” oraz sposobów zdobywania tych kwalifikacji, ich sprawdzania i zaświadczania ${ }^{109}$.

103 P. Lechowski, Problemy...., s. 102, S.A. Kondek, Papierowa..., s. 90.

104 AAN, Wydz. Ośw. KC PZPR, 237/XVII-228, Biblioteki i Czytelnictwo, 27.I.1949-22.II.1952.

105 AAN, Wydz. Ośw. KC PZPR, 237/XVII-228, Biblioteki i Czytelnictwo, 27.I.1949-22.II.1952. Protokół z posiedzenia w sprawie koordynacji pracy bibliotecznej odbytego w dn. 11.II.49 r.; Nb. Jerzy Maj w opracowaniu Biblioteki publiczne liczbach 1945-1990 na tle innych instytucji kultury (Warszawa 1996, s. 24) podaje liczbę 934 bibliotek publicznych czynnych pod koniec 1948 r. Ilość placówek obliczona przez J. Maja wynika zapewne $\mathrm{z}$ innego sposobu ich kwalifikowania do kategorii bibliotek publicznych.

106 AAN, MOśw., NDB, 6728, J. Grycz, Plan pracy na rok 1949.

107 „Razem 3984 biblioteki samorządowe”, zob. AAN, Wydz. Ośw. KC PZPR, 237/XVII-228, Biblioteki i Czytelnictwo, 27.I.1949-22.II.1952. Ostatecznie w 1951 r. sieć obejmowała ogółem 4187 biblioteki i filii, w tym 1246 w miastach i 2941 na wsi. Łącznie posiadały ok. 13,5 mln woluminów, z czego 5 mln na wsi. Funkcjonowało też ok. 25 tys. punktów bibliotecznych, zob. P. Lechowski, Problemy...., s. 107.

${ }^{108}$ BN, rps akc. 14927, t. 3, J. Grycz, Akcja biblioteczna.

109 J. Grycz, Polska polityka..., s. 81-88. 
J. Gryczowi nie pozwolono na dokończenie prac związanych z organizacją bibliotekarstwa. Był zresztą świadom, że jego pozycja w ministerstwie jest tym razem poważnie „zagrożona”. Już w listopadzie tego roku poinformował M. Łodyńskiego ${ }^{110}$, że przewiduje możliwość swego odejścia z NDB ${ }^{111}$. Rzeczywiście, na początku lutego 1949 r. J. Grycz został zwolniony ,ze skutkiem natychmiastowym” ze stanowiska Naczelnego Dyrektora Bibliotek z powodu „uchybień służbowych”112. Według Zygmunta Kolankowskiego ${ }^{113}$ - przyczyną był ,zarzut wydania - z pominięciem właściwej drogi służbowej - w ręce ambasady holenderskiej w Warszawie dużego zestawu druków i rękopisów"114. Były to zbiory Archiwum Międzynarodówki Socjalistycznej w Amsterdamie. J. Grycz i Witold Suchodolski (Dyrektor Wydziału Archiwów Państwowych Ministerstwa Oświaty ${ }^{115}$ ) przekazali je Holendrom nie informując o tym ani Ministerstwa Oświaty, ani Ministerstwa Spraw Zagranicznych ${ }^{116}$. W efekcie również W. Suchodolski został usunięty ze stanowiska. Sprawa ta mogła wywołać jeszcze poważniejsze konsekwencje. Dlatego A. Łysakowski z ulgą przyjął informację J. Grycza, że zaniechano wobec niego ,zamierzonej, a nieuzasadnionej akcji według rygorów najostrzejszych"117. W marcu J. Grycz podjął pracę w Bibliotece Narodowej.

\section{Sytuacja bibliotekarstwa po zwolnieniu J. Grycza z NDB}

\section{5 marca J. Grycz pisał do A. Łysakowskiego:}

Dziękuję Ci serdecznie za przyjacielskie słowa [w liście z 11 lutego ${ }^{118}$ ], które w okresie pierwszej depresji wzmocniły mnie i ukoiły. Dziś jestem przekonany, że dla mnie osobiście lepiej będzie pracować dla bibliotekarstwa naszego na innym, mniej eksponowanym stanowisku. Na razie od dwóch dni jestem w Bibliotece Narodowej ku-

${ }^{110}$ M. Łodyński do A. Łysakowskiego, [w:] Bibliotekarstwo polskie..., s. 291, 293-294.

${ }^{111}$ M. Łodyński do A. Łysakowskiego, 15 listopada 1948, [w:] Bibliotekarstwo polskie..., s. 292. ca1949.

112 BN, rps akc. 14927 , t. 3, pismo Ministerstwa Oświaty Nr I Pers-4827/49, 8 mar-

${ }^{113}$ W latach 1948-1949 pracownik Wydziału Stosunków Międzynarodowych Ministerstwa Oświaty.

114 Cyt. za H. Łaskarzewska, Józef Grycz wobec problemów integralności i prawa własności księgozbiorów, s. 7, maszynopis z października 2012 r. w posiadaniu autorki.

115 W. Suchodolski pracował w Archiwach Państwowych jeszcze przed wojną, a podczas okupacji był kierownikiem sekcji archiwów w Delegaturze Rządu na Kraj.

${ }^{116}$ H. Łaskarzewska, Józef Grycz..., s. 7.

${ }^{117}$ BN, rps akc. 14966, t. 4, A. Łysakowski do J. Grycza, 2 kwietnia 1949.

118 Tamże, A. Łysakowski do J. Grycza, 11 lutego 1949; zob. też Bibliotekarstwo polskie..., s. 312, przypis 19. 
stoszem z 4 [grupą uposażenia ${ }^{119}$ ] i zastępcą dyrektora - obok [Ksawerego] Świerkowskiego [...]. Chciałbym podzielić się z Tobą jeszcze jedną myślą i prosić Cię o decyzję. Wydaje mi się, że w związku z usunięciem mnie ze stanowiska naczelnego dyrektora bibliotek byłoby może uzasadnione, gdybym na Zjeździe Delegatów [Kół] ZBiAP przedstawił dotychczasową akcję biblioteczną. Dla większości delegatów taki całokształt może byłby interesujący, ja zaś w ten sposób zdałbym niejako sprawę z mojej działalności [...]. W razie pozytywnego rozstrzygnięcia musiałbyś też jako prezes polecić wstawienie tego referatu do programu Zjazdu ${ }^{120}$.

Niestety, mimo starań A. Łysakowskiego wystąpienie J. Grycza nie znalazło się w programie Zjazdu ${ }^{121}$. Informując o tym J. Grycza, A. Łysakowski stwierdził, że „,niektórzy koledzy radzi już zapomnieć o Twojej wczorajszej roli"122. Było to to dla J. Grycza tym boleśniejsze, że w trakcie obrad pośrednio skrytykowano jego działalność jako Naczelnego Dyrektora Bibliotek. Otóż Jadwiga Filipkowska-Szemplińska wskazała na braki i niedociągnięcia w dotychczasowym przebiegu „akcji bibliotecznej”. Jej niezadowolenie wzbudziła zwłaszcza obecność w księgozbiorach wydawnictw „przesiąkniętych ideałami świata burżuazyjnego”. Jako najważniejsze problemy bibliotekarstwa wymieniła:

1. ścisły związek pomiędzy formą ustroju państwa a rozwojem bibliotek;

2. konieczność zerwania $\mathrm{z}$ apolitycznością oświaty;

3. rozwój i niedomagania akcji bibliotecznej;

4. wychowawcza rola bibliotekarza w służbie przemian ustrojowych;

5. postulaty wychowania odpowiednich kadr pracowników bibliotecznych ${ }^{123}$.

${ }^{119}$ A. Łysakowski uważał degradację J. Grycza za precedens, który, w stosunku do bibliotekarzy, ułatwi „dokonanie następnych analogicznych wypadków i dlatego Związek [ZBiAP] powinien się o to upomnieć, choć można było - teoretycznie - zrobić to już wcześniej, przy poprzednich wypadkach”. W liście do J. Grycza pisał, że chce ,jeszcze wierzyć w rzeczowość i walczyć o nią. Może przeważy ona w Twym położeniu i w stosunkach najbliższych", zob. BN, rps akc. 14966, t. 4, A. Łysakowski do J. Grycza, 2 kwietnia 1949.

${ }^{120}$ J. Grycz do A. Łysakowskiego, 25 marca1949, [w:] Bibliotekarstwo polskie..., s. 310.

${ }^{121} \mathrm{~A}$. Łysakowski wysłał pismo do Prezydium ZBiAP popierające dołączenie referatu J. Grycza do programu Zjazdu. J. Gryczowi wyjaśnił zaś, że nie mógł „«polecić» [...] wstawienia tego punktu do programu zebrania”, ponieważ program został już rozesłany do uczestników Zjazdu oraz dlatego, że nie mógł „arbitralnie sam decydować” w tej sprawie, zob. BN, rps akc. 14966, t. 4, A. Łysakowski do J. Grycza, 2 kwietnia 1949.

Według Alodii Kaweckiej-Gryczowej nie dopuszczono J. Grycza do głosu „wskutek sprzeciwu niepowołanych czynników, wywierających [...] nacisk na ówczesne władze Związku", zob. J. Grycz, Polska polityka..., s. 71.

${ }_{122}$ BN, rps akc. 14966, t. 4, A. Łysakowski do J. Grycza, 2 kwietnia 1949.

123 J. Filipkowska-Szemplińska, Zadania Z.B.iA.P. w Polsce Ludowej. Referat wygtoszony na Zjeździe Delegatów ZBiAP we Wrocławiu 7.IV.1949, „Bibliotekarz”, marzec-kwiecień 1949, nr 3-4, s. 38-39. 
Od początku 1949 r. realizację tych postulatów nadzorował Wydział Oświaty i Kultury KC PZPR. Za sprawy bibliotekarstwa odpowiadał w nim Zbigniew Pomianowski, uprzednio zatrudniony w Ministerstwie Oświaty. Partia zwróciła przede wszystkim uwagę na problem nadzoru nad bibliotekami, który oceniała jako „więcej niż niedostateczny” - zorganizowano bowiem „dużą ilość bibliotek, ale nie skontrolowano ich działalności" ${ }^{24}$. Szczególnie źle oceniano w KC pracę NDB nad polityczną oceną wydawnictw oraz doborem książek do bibliotek powszechnych i szkolnych. Przy czym zarzuty w tym zakresie dotyczyły również działalności Dyrekcji pod kierownictwem Józefa Skrzypka, który zastąpił J. Grycza ${ }^{125}$.

Partia przywiązywała wielką wagę do „oczyszczenia” księgozbiorów bibliotecznych z wydawnictw „o treści politycznie wrogiej i szkodliwej”, „przesiąkniętych duchem wstecznym, burżuazyjnym, rozkładowym, kosmopolitycznym, antymaterialistycznym i idealistycznym" 126 . Po zmianie kierownictwa NDB zorganizowano w KC kilka narad w tej sprawie w marcu, maju i czerwcu 1949 r. W ich trakcie podkreślano zwłaszcza konieczność lepszej współpracy i koordynacji działań władz bibliotecz-

124 AAN, Wydz. Ośw. KC PZPR, 237/XVII-231, Biblioteki i Czytelnictwo, 27 I 194922 II 1952, Wnioski z posiedzenia odbytego w dniu 28 XII 1949 r. w sprawie sieci bibliotecznej.

${ }^{125}$ J. Skrzypek tak nakreślił program prac NDB pod swoim kierownictwem: „Uważając biblioteki za ważny instrument walki klasowej, oraz narzędzie uświadomienia szerokich mas społeczeństwa, i podnoszenia ich na wyższy stopień kulturalny N.D.B. widzi konieczność intensywniejszego niż dotychczas wzmożenia pracy na swoim odcinku". Obok przejęcia przez państwo wszystkich bibliotek samorządowych i organizacji tzw. czytelnictwa „masowego” J. Skrzypek uznał za konieczne:

- pracę nad udoskonaleniem szkolenia bibliotekarzy, „zwłaszcza o ile idzie o stronę ideologiczną";

- nadzór i kontrolę, która „dotychczas prawie nie istnieje. Najpilniejszym zadaniem jest dopilnowanie nad należytym funkcjonowaniem bibliotek oraz obsługą rzesz czytelniczych. Chodzi o to aby ogromne sumy wydatkowane na ten cel przez państwo nie były martwe";

- oczyszczanie księgozbiorów bibliotecznych z książek „złych i społecznie szkodliwych. [...] W tym zakresie przygotuje N.D.B. spisy książek podlegających wycofaniu ze zbiorów bibliotecznych”.

- uzupełnianie księgozbiorów bibliotecznych poprzez centralny zakup Ministerstwa Oświaty oraz ,z funduszów własnych bibliotek. Wymaga to zwłaszcza w drugim wypadku, dokładnej kontroli i nadzoru. W tym celu N.D.B. przez przygotowanie ocen książek świadczy pomoc poszczególnym bibliotekom, udzielając wskazówek i zleceń".

Zob. AAN, MOśw., NDB,6728, J. Skrzypek, Plan pracy na rok 1950. W celu realizacji tego programu latem 1949 r. opracowano projekt nowej organizacji NDB, zob. AAN, MOśw., NDB, 6724.

${ }^{126}$ E. Iwańczak, III Plenum Komitetu Centralnego Polskiej Zjednoczonej Partii Robotniczej a zadania Zwiąku Bibliotekarzy i Archiwistów Polskich, Przegl. Bibliot., 18:1950, z. 2, s. 101. 
nych i GUKPPiW ${ }^{127}$. Dla zapewnienia właściwego doboru materiałów do bibliotek nakazano też powołanie w NDB stałej „komisji doboru książek" (powstała jako Komisja Oceny Książek) z udziałem przedstawicieli GUKPPiW. Jej głównym zadaniem był przegląd

wszystkich wydawnictw i literatury pięknej - beletrystyki - książek popularno-naukowych i innych książek, które wchodzą w skład zbiorów [...] bibliotek, a które ukazały się od momentu wyzwolenia Kraju do chwili obecnej i które ukazują się. Komisja ta będzie z jednej strony dostarczała tytuły książek, które będą dopuszczane do bibliotek szkolnych i powszechnych, a z drugiej strony będzie dawała materiał do wydawania przez G.U.K.Pr. indeksu książek, które nie należy dopuszczać do bibliotek publicznych ${ }^{128}$.

W czasie tych narad opracowano też plan ogólnokrajowej „czystki” w zbiorach bibliotek powszechnych. Przystąpiono do niej od 1 lipca na podstawie okólników Rady Państwa ${ }^{129}$ i Naczelnego Dyrektora Bibliotek J. Skrzypka ${ }^{130}$. Akcja trwała oficjalnie do 30 września. Realizowały ją dwu-trzyosobowe „komisje robocze”, działające pod nadzorem „trójek partyjnych”131. Za przebieg „czystki” w poszczególnych województwach odpowiadali pierwsi sekretarze KW PZPR ${ }^{132}$. Przy selekcji druków po-

127 AAN, Wydz. Ośw. KC PZPR, 237/XVII-228, Biblioteki i Czytelnictwo, 27.I.1949-22.II.1952, Protokół z konferencji bibliotecznej przedstawicieli Urzędów i Instytucji Centralnych odbytej w KC PZPR w dniu 2.III.49 r., Warszawa 4 marca 1949. W zebraniu uczestniczyli: kierownik Biblioteki KC PZPR Wanda Michalska i Z. Pomianowski (Wydz. Ośw. KC PZPR), Janina Kraczkiewicz (Rada Państwa), J. Filipkowska-Szemplińska (Ministerstwo Administracji), J. Skrzypek, Z. Żołątkowska, Zofia Hryniewicz (NDB), Kazimierz Wojciechowski (Towarzystwo Uniwersytetów Robotniczych i Ludowych Rzeczypospolitej Polskiej), Bilingowa (Związek Samopomocy Chłopskiej) i Karpowski (GUKPPiW).

128 AAN, Wydz. Ośw. KC PZPR, 237/XVII-229, Oczyszczenie (selekcja) księgozbiorów bibliotecznych, 1950-1952, Maszynopis roboczy z 2 maja 1949.

${ }^{129}$ Okólnik z czerwca 1949 r. podpisany przez Szefa Kancelarii Rady Państwa Kazimierza Mijala głosił m.in., że: „Na obecnym etapie [...] akcji bibliotecznej [...] nasuwa się konieczność ścisłej kontroli nad działalnością i funkcjonowaniem bibliotek wszystkich typów, a przede wszystkim bibliotek powszechnych (samorządowych). Jako jeden z bardzo ważnych momentów w tym względzie staje na porządku dziennym [...] zagadnienie usunięcia z księgozbiorów bibliotecznych książek złych, wrogich ustrojowi ludowemu i społecznie szkodliwych; książki tego rodzaju w wielkiej nieraz ilości zalegają półki biblioteczne i wypożyczane są czytelnikom”. Okólnik został dołączony do „ściśle tajnego” pisma obiegowego sygnowanego przez kierownika Wydziału Oświaty KC PZPR Józefa Kowalczyka i kierownika Działu Propagandy Oświaty i Kultury Jerzego Albrechta. Pismo adresowane było do pierwszych sekretarzy. Zob. KW PZPR. Zob. AAN, Wydz. Ośw. KC PZPR, 237/XVII-229, Oczyszczenie (selekcja) księgozbiorów bibliotecznych, 1950-1952,

130 „Poufny” okólnik J. Skrzypka adresowany do kuratoriów okręgów szkolnych również został załączony do pisma J. Kowalczyka i J. Albrechta.

131 Pismo J. Kowalczyka i J. Albrechta.

132 Tamże. 
sługiwano się Wykazem książek podlegających niezwłocznemu wycofaniu obejmującym 14 autorów i 518 tytułów dzie1 ${ }^{133}$. Podsumowując akcję anonimowy autor Notatki o dalszej akcji oczyszczania bibliotek mógł zatem z satysfakcją stwierdzić, iż „Kontrola i odpowiedzialność” (ktoś wykreślił słowo „odpowiedzialność”) za czystki w księgozbiorach bibliotecznych spoczywa już „w rękach Partii”

Wydział Oświaty i Kultury KC zajął się też problemem odpowiedniego uzupełniania księgozbiorów. Kilka dni po zwolnieniu J. Grycza z NDB odbyło się zebranie (11 lutego 1949 r.) w sprawie koordynacji pracy bibliotecznej. W jego trakcie Wanda Michalska - ówcześnie kierowniczka Biblioteki KC PZPR ${ }^{135}$ - stwierdziła że jednym z głównych zadań NDB powinno być ,zasilenie bibliotek książkami marksistowskimi"136. Zgodnie z tym zaleceniem Dyrekcja starała się poprzez centralny zakup wydawnictw zapełniać księgozbiory bibliotek powszechnych pozycjami służącymi budowie socjalizmu ${ }^{137}$. W efekcie na półkach bibliotecznych znalazła się duża ilość publikacji propagandowych, literatury socrealistycznej i klasyków marksizmu-leninizmu ${ }^{138}$ oraz innych ,bubli zalegających magazyny księgarskie”, jak to określił T. Zarzębski139.

${ }^{133}$ Wykaz ksiażek... został załączony do pisma J. Kowalczyka i J. Albrechta.

134 AAN, Wydz. Ośw. KC PZPR, 237/XVII-229, Oczyszczenie (selekcja) księgozbiorów bibliotecznych, 1950-1952. Na temat następnych „czystek” w księgozbiorach bibliotecznych zob. m.in.: AAN, MOśw. NDB, 6987, Kontrole bibliotek; M. Korczyńska-Derkacz, Ksiażki szkodliwe politycznie..., s. 341-353.

${ }^{135}$ W. Michalska była z wykształcenia krawcowa. W przyszłości zastąpiła J. Skrzypka na stanowisku dyrektora Centralnego Zarządu Bibliotek (CZB) powołanego w miejsce NDB, zob. Kondek, Papierowa..., s. 98-99.

136 AAN, Wydz. Ośw. KC PZPR, 237/XVII-228, Biblioteki i Czytelnictwo, 27.I.1949-22.II.1952, Protokół z posiedzenia w sprawie koordynacji pracy bibliotecznej odbytego w dn. 11.II.49 r., W zebraniu wzięli udział: Z. Żołątkowska, J. Skrzypek, J. Filipkowska-Szemplińska, Z. Hryniewicz, kierownik Wydziału Kultury i Oświaty Komisji Centralnej Związków Zawodowych Stefania Cieślikowska, K. Wojciechowski, przedstawicielka „Czytelnika” Lidman, W. Michalska i Z. Pomianowski.

137 J. Cyrankiewicz, Zadania masowych organizacji spotecznych $w$ ofensywie kulturalnej. Przemówienie wygtoszone na plenarnym posiedzeniu Komisji Gtównej do Spraw Kultury w dniu 17 czerwca 1949 r., „Biuletyn Informacyjny Komisji Głównej do Spraw Kultury", 1949, nr 1, s. 4-5.

138 Budowane w ten sposób księgozbiory, zwłaszcza od podstaw w nowych bibliotekach, były z zasady pozbawione wydawnictw ,ideologicznie obcych”. Np. według Sprawozdania $z$ akcji oczyszczania bibliotek, przesłanego do Wydziału Oświaty KC PZPR przez Instruktora Oświatowego Zb. Stołbiaka z Kielc, trójki partyjne i komisje robocze wycofały w 1952 r. 533 książki ,ideologicznie obce” z bibliotek publicznych i szkolnych województwa kieleckiego. Stwierdzono przy tym, że „bardzo duży procent tych bibliotek $(85 \%)$ nie posiadało księgozbioru, w którym byłyby książki podlegające wycofaniu. Tłumaczy się to tym, że biblioteki te zakładane już po 45 roku otrzymywały książki odgórnie przez poszczególne resorty”. Zob. AAN, Wydz. Ośw. KC PZPR, 237/XVII-229, Oczyszczenie (selekcja) księgozbiorów bibliotecznych, 1950-1952.

139 T. Zarzębski: Uwagi nad życiem Józefa Grycza..., s. 22. 
Po odejściu J. Grycza z NDB próbowano nawet zakwestionować podstawy organizacji sieci samorządowych bibliotek powszechnych. Uchwalona przez Sejm w listopadzie 1948 r. kwota 150 mln zł na wynagrodzenia dla kierowników punktów bibliotecznych została decyzją Kancelarii Rady Państwa z 14 kwietnia 1949 r. przeznaczona na inne wydatki bibliotek samorządowych. Stwierdzono bowiem, że:

prowadzenie bibliotek gminnych winne być w ręku czynnika społecznego - praca ta nie powinna być wynagradzana. Zdaniem Rady Państwa winna się tym zająć taka organizacja jak Z.M.P [Związek Młodzieży Polskiej]

Zbulwersowany tą decyzją Z. Pomianowski informował J. Skrzypka, iż w konsekwencji do kuratoriów okręgów szkolnych przychodzą meldunki, że „akcja biblioteczna się załamie - gdyż bibliotekarze gminni rezygnują nie otrzymując obiecanych poborów". Kończąc stwierdzał, że choć B. Bierut poparł stanowisko Rady Państwa, to ma nadzieję, że po rozmowie $\mathrm{z}$ nim uda się tę sprawę załatwić ${ }^{140}$. Rzeczywiście, problem rozwiązano z korzyścią dla bibliotekarzy i sieci.

W następnych miesiącach zdecydowano się na upaństwowienie bibliotek powszechnych. 28 września 1949 r. ukazał się Okólnik nr 63 Rady Państwa oddający biblioteki wojewódzkie pod kontrolę administracji państwowej ${ }^{141}$. Pod koniec tego roku zaplanowano upaństwowienie innych placówek. Świadczą o tym Wnioski $z$ posiedzenia odbytego $w$ dniu 28.XII.1949 r. w sprawie sieci bibliotecznej. Uczestnicy zebrania, zwołanego z inicjatywy Wydziału Oświaty KC PZPR, uznali „za najważniejszą pracę na rok 1950 upaństwowienie bibliotek samorządowych"142. Dokonało się to za sprawą Ustawy o terenowych organach jednolitej władzy państwowej z 20 marca 1950 r. Likwidując samorząd lokalny ustawa oddała biblioteki powiatowe i gminne pod kontrolę rad narodowych ${ }^{143}$.

Jak stwierdził T. Zarzębski bez twórców i animatorów polityki bibliotecznej „rama organizacyjna” całego bibliotekarstwa określona przez Dekret o bibliotekach... „rozsypała się"144. Jeszcze w lutym 1949 r. nowy Na-

140 AAN, Wydz. Ośw. KC PZPR, 237/XVII-231, Notatka Z. Pomianowskiego załączona jest do pisma J. Skrzypka do J. Kowalczyka z 27 maja 1949.

141 „Rada Narodowa”, 1949, nr 20, s. 20.

142 AAN, Wydz. Ośw. KC PZPR, 237/XVII-228, Biblioteki i Czytelnictwo, 27.I.1949-22.II.1952.

143 Dz.U. RP, 1950, nr 11-12, s. 162-166; zob. też A. Bocheński, Bibliotekarstwo powszechne w nowym uktadzie prawno-administracyjnym, „Bibliotekarz”, listopad-grudzień 1950, nr 11-12, s. 162-166.

144 T. Zarzębski, Geneza..., s. 289-290. 
czelny Dyrektor Bibliotek J. Skrzypek ocenił zdecydowanie negatywnie działalność Państwowego Instytutu Książki (PIK), który m.in. wspierał naukowo realizację zapisów dekretu. J. Skrzypek stwierdził, że Instytut należy zlikwidować ${ }^{145}$. Taka decyzja została podjęta ostatecznie w lipcu, we wrześniu PIK zawieszono, a w marcu 1950 r. oficjalnie „zniesiono” ${ }^{146 .}$ W październiku 1950 r. biblioteki uczelniane znalazły się w gestii Ministerstwa Szkół Wyższych i Nauki. Rok później - na mocy ustawy z 30 października 1951 r. - sprawy bibliotek powszechnych i zbiorów bibliotecznych przejęło Ministerstwo Kultury i Sztuki (MKiSz). Opiekę nad bibliotekami publicznymi sprawował odtąd Centralny Zarząd Bibliotek (CZB). Miał on przejąć wszystkie funkcje NDB, ale w praktyce zajął się tylko bibliotekami podlegającymi MKiSz. W Ministerstwie Oświaty pozostały natomiast sprawy bibliotek szkolnych i pedagogicznych ${ }^{147}$.

Zwolnienie J. Grycza z NDB symbolizuje również zmiany zachodzące w środowisku bibliotekarskim. Istotę owego procesu tak opisywał na początku 1948 r. M. Łodyński:

nie zawsze widoczny $[\ldots]$ nurt $[\ldots .$.$] jest [\ldots]$ - jak na wszystkich odcinkach życia publicznego - jednokierunkowy. Zmierza mianowicie do politycznego «zgleichszaltowania» przy częściowej likwidacji i przejściowym tolerowaniu «ancien-regimowych» Mohikanów zawodowych: jeszcze rok, jeszcze dwa lata, jeszcze... najwyżej 5 lat, tj. tyle, ile wymaga podrośnięcie jednego «dobranego» pokolenia uniwersyteckiego ${ }^{148}$.

Niebawem okazało się, że aktywiści partyjni obwinili właśnie „ancienregimowych Mohikanów zawodowych” o to, że biblioteki powszechne

nie potrafiły włączyć się w nurt zachodzących przemian. Nie stały się orężem walki klasowej, nie były czynnikiem wychowawczym; wkładem swej pracy nie zaważyly w dostatecznym stopniu w rewolucji kulturalnej Polski [...] błędem minionego trzylecia w zakresie bibliotecznym było niedostateczne zwrócenie uwagi na zagadnienie oczyszczenia aparatu bibliotecznego z wrogich i szkodliwych jednostek, które pod płaszczykiem źle pojętej «fachowości» usiłowały prowadzić wrogą i szkodliwą robotę 149 .

${ }^{145}$ M. Korczyńska-Derkacz, Państwowy Instytut..., s. 248.

146 Rozporzadzenie Rady Ministrów z dnia 3 marca 1950 w sprawie zniesienia PIK. Dz.U. RP, 1950, nr 7, poz. 65.

${ }^{147}$ Kondek, Papierowa..., s. 98-99.

148 M. Łodyński do A. Łysakowskiego, 23 stycznia 1948, [w:] Bibliotekarstwo polskie..., s. 287.

149 Z. Kempka, Rola bibliotek w planie 6-letnim, „Bibliotekarz”, marzec-kwiecień 1950, nr 3-4, s. 35. 
Należało więc pozbyć się z bibliotek osób wychowanych „w atmosferze sanacyjnego dwudziestolecia", pochłoniętych przede wszystkim „kwestiami swego rzemiosła”, nierozumiejących roli i znaczenia bibliotek w Polsce Ludowej, wykazujących się brakiem „właściwego uzbrojenia ideologicznego" i powierzchowną znajomością marksizmu oraz tolerujących w bibliotekach obecność bezwartościowej lub „obojętnej” ideologicznie, a nawet „wrogiej literatury faszystowskiej” ${ }^{150}$. Odnosiło się to do takich bibliotekarzy, jak m.in. J. Grycz, M. Łodyński, E. Kuntze, A. Łysakowski, Ryszard Przelaskowski, J. Janiczek i F. Sedlaczek,. Jako profesjonaliści nie akceptowali oni sytuacji, w której np. „18-letnia panienka" obejmowała kierownictwo ważnej biblioteki specjalnej ${ }^{151}$. Nie chcieli popierać też nowych metod pracy bibliotekarskiej niemających nic wspólnego z fachowością, np. tzw. „współzawodnictwa pracy”. Dlatego sukcesywnie usuwano ich z bibliotek - w pierwszej kolejności ze stanowisk kierowniczych ${ }^{152}$, bądź sami odchodzili z zawodu tak jak J. Janiczek $^{153}$.

„Starą kadrę" bibliotekarską stopniowo wymieniano na „nowy, młody element" 154 . Były to często osoby niekompetentne, ,analfabeci” jak pisał E. Kuntze ${ }^{155}$, ale cieszące się zaufaniem partii. Nowi bibliotekarze mieli stać się „żołnierzami rewolucji kulturalnej”, wychowawcami narodu i ,inżynierami duszy ludzkiej” wyszkolonymi w ideologii marksistowsko-leninowskiej, stosującymi metody bibliotekarstwa radzieckiego $\mathrm{w}$ „walce o masowego czytelnika"156. Aby ich przygotować do wypełniania tej roli przystąpiono do zmian w programach kursów organizowa-

${ }^{150}$ Zastosowanie uchwat III Plenum KC PZPR w pracy Zwiazku Bibliotekarzy $i$ Archiwistów Polskich, „Bibliotekarz”, listopad-grudzień 1949, nr 11-12, s. 179 (numer ukazal się w 70-lecie urodzin Stalina); Z. Kempka, Rola bibliotek..., s. 35-37; E. Iwańczak, III Plenum..., s. 100-104.

${ }^{151}$ J. Grycz do A. Łysakowskiego, 26 marca 1945, [w:] Bibliotekarstwo polskie..., s. 306.

152 Dotyczyło to m.in. NDB. Władze nie mogły bowiem tolerować sytuacji, w której np. w Wydziale Bibliotek Naukowych Dyrekcji nie było „ani jednego członka Partii. W pracy wydziału wyczuwa się brak podejścia politycznego. Naczelnik [M. Łodyński] jest człowiekiem niezwiązanym z dzisiejszą rzeczywistością (wiek ponad 60 lat)", zob. AAN, MOśw., NDB, 6728, Sprawozdanie Komisji do przeprowadzenia analizy pracy Naczelnej Dyrekcji Bibliotek. [marzec 1950]. W skład komisji weszli m.in. Z. Pomianowski, W. Michalska i J. Skrzypek.

${ }^{153}$ W 1950 r. J. Janiczek podjął pracę w Ludowej Spółdzielni Wydawniczej.

${ }^{154}$ AAN, MOśw. NDB, 6728, J. Skrzypek, Plan pracy Nacz. Dyr. Bibl. na IV kwartał 1950 r.; Ogólny plan pracy Naczelnej Dyrekcji Bibliotek na okres od dnia 1 IX do 31XII 50 r.

${ }_{155}$ BN, rps akc. 14966, t. 3b, E. Kuntze do J. Grycza, 2 czerwca 1948.

${ }^{156}$ E. Ochab, Bibliotekarz żotnierzem rewolucji kulturalnej, „Bibliotekarz”, 1952, nr 3, s. 65; Po ogólnokrajowej naradzie bibliotekarzy w sprawie czytelnictwa, „Bibliotekarz”, 1952, nr 3, s. 69. 
nych dla kierowników i pracowników bibliotek powszechnych. Pod wpływem krytyki władz zwierzchnich jeszcze w okresie dyrekcji J. Grycza (w 1948 r.) zawarto w programach szkoleń bibliotekarskich treści ideologiczne ${ }^{157}$. Według działaczy partyjnych zmiany te były niewystarczają$\mathrm{ce}^{158}$. Z tego powodu Wydział Oświaty i Kultury KC PZPR zainteresował się w 1949 r. działalnością Ośrodka Szkolenia Bibliotekarzy w Jarocinie $^{159}$. Placówką kierował F. Sedlaczek, który przeszedł do niej z NDB ${ }^{160}$. W październiku 1950 r. Ośrodek skontrolowano. W efekcie lustracji postanowiono usunąć F. Sedlaczka ze stanowiska kierownika161 i mianować na jego miejsce „fachowca politycznie i ideologicznie pewnego"162. Z czasem przeprowadzono również zmiany w kadrze wykładowców tej placówki i w jej programie nauczania. Przy czym treści ideologiczne programu były uzgadniane z KC PZPR ${ }^{163}$. Jednak mimo starań władz partyjnych i bibliotecznych jeszcze na początku 1952 r. Józef Kowalczyk (kierownik Wydziału Oświaty i Kultury KC PZPR) podkreślał „słabość polityczną kadry bibliotekarskiej”164. Dlatego wzmocniono

157 P. Lechowski, Problemy..., s. 104.

${ }^{158}$ AAN, Wydz. Ośw. KC PZPR, 237/XVII-228, Biblioteki i Czytelnictwo, 27.I.1949-22.II.1952.

${ }^{159}$ Uczestnicy narady zorganizowanej 28 grudnia 1949 r. przez Wydział Oświaty i Kultury KC PZPR stwierdzili, że: „Nie wiadomo jak wyglądają w Jarocinie kursy [...], gdyż poza jednym wyjazdem tow. Żołądkowskiej [sic! właściwie Żołątkowska] (2 dni) nikt do Jarocina nie zagląda. Dużego zaufania do pracy w wymienionym ośrodku mieć nie można. (Kierownik bezpartyjny)".ob. AAN, Wydz. Ośw. KC PZPR, 237/XVII-228, Biblioteki i Czytelnictwo, 27.I.1949-22.II.1952.

${ }^{160}$ Uzyskał roczny urlop w NDB i objął w tym czasie kierownictwo jarocińskiego ośrodka.

${ }^{161}$ Prowadząca kontrolę tow. Anna Betmann stwierdziła m.in., że dyrektor Ośrodka to „bezpartyjny [...]. Człowiek zupełnie niezorganizowany, co uwidacznia się pracach całego ośrodka. Człowiek starej daty i na pewno nie naszych poglądów. Twierdzi, że jest przede wszystkim fachowcem o od tej strony wykazuje swoją dbałość. Trudno to było sprawdzić w ciągu jednego dnia. Niemniej wykład, na którym akurat byłam, był i od strony fachowej i od strony pedagogicznej i od strony ideowej z gruntu zły”. Zob. AAN, Wydz. Ośw. KC PZPR, 237/XVII-23, [A. Betmann], Sprawozdanie z lustracji [...] Ośrodka Szkolenia Bibliotekarzy w Jarocinie 23.X.-28.X.50 r. Warszawa 4 listopada 1950. W lustracji Ośrodka brał także udział tow. Andrzejczak z Wydziału Propagandy Oświaty i Kultury KW PZPR w Poznaniu. W notatce pokontrolnej stwierdzit: „Ob. dyr. Sedlaczek Franciszek, bezp. Niewątpliwie dobry fachowiec od zagadnień bibliotecznych, ale nie zdający sobie sprawy z tego jakiej postawy ideologicznej wymaga Polska Ludowa od instruktorów bibl., których on kształci”. Tamże, Andrzejczak, Notatka z wizytacji Państwowego Ośrodka Kształcenia Bibliotekarzy w Jarocinie, odbytej w dniu 26 i 27.10.1950 r., 13 listopada 1950.

162 AAN, Wydz. Ośw. KC PZPR, 237/XVII-231, Wnioski [pokontrolne].

${ }^{163}$ AAN, Wydz. Ośw. KC PZPR, 237/XVII-23, [A. Betmann], Sprawozdanie z lustracji...

164 AAN, Wydz. Ośw. KC PZPR, 237/XVII-229, Oczyszczenie (selekcja) księgozbiorów bibliotecznych, 1950-1952, J. Kowalczyk, Notatka w sprawie oczyszczania bibliotek, 22 lutego 1952. 
kontrolę nad bibliotekarzami w imię czujności nad ich podstawą ideową i doborem odpowiednich wydawnictw do księgozbiorów ${ }^{165}$.

Dobre podsumowanie opisywanego wyżej procesu zmian kadrowych w bibliotekarstwie stanowi komentarz A. Łysakowskiego na temat przebiegu Zjazdu Delegatów Kół ZBiAP w kwietniu 1949 r. we Wrocławiu, w trakcie którego ustąpił z funkcji przewodniczącego Związku ${ }^{166} .6$ maja 1949 r. pisał mianowicie do Mikołaja Dzikowskiego:

Dodaj do tego sprawę Grycza i Suchodolskiego, będziesz miał jasny pogląd na nowy kierunek w bibliotekarstwie naszym. Tym smutniejsze to wszystko, że wydaje mi się niekonieczne, bo w gruncie rzeczy chcemy tego samego - rozwoju i postępu książki - i jesteśmy ludźmi dobrej woli ${ }^{167}$.

Niestety, aktywiści upolitycznionego bibliotekarstwa - z osób wymienionych w niniejszym artykule można wymienić na przykład J. Skrzypka, W. Michalską, J. Filipkowską-Szemplińską, Edwarda Iwańczaka i Zbigniewa Kempkę - nie byli osobami dobrej woli. Jak zauważył M. Łodyński reprezentowali stronę, która „wygrała w całości” i „nie omieszka tego wyzyskać”"168 przyspieszając m.in. „czyszczenie szeregów”. W efekcie Jan Muszkowski skonstatował w 1952 r.:

Kiedy znalazłem się wczoraj rano w gronie uczestników naszego zjazdu [ogólnopolskiej narady bibliotekarzy], stwierdziłem fakt, który mnie zastanowił. Mianowicie zdziwiło mnie to, że w tak wielkim zgromadzeniu, zdaje się 700 osób, tak mało widzę znajomych, maleńką garsteczkę znajomych ${ }^{169}$.

\section{Zakończenie}

Na realizacji programu budowy bibliotekarstwa powszechnego, którego współautorem i współwykonawcą był J. Grycz, zaważyła zasada władz komunistycznych, wedle której „oświatę i kulturę socjalistyczną należy budować na «pustyni», to jest po uprzednim usunięciu z życia społecznego dorobku oświatowego i kulturalnego okresu poprzedniego"170.

165 E. Iwańczak, III Plenum..., s. 100.

166 A. Łysakowski do M. Łodyńskiego, 13 kwietnia 1949, [w:] Bibliotekarstwo polskie..., s. 295, 301.

167 Cyt. za M. Derkacz, Państwowy Instytut..., s. 261.

168 M. Łodyński do A. Łysakowskiego, 11 kwietnia 1949, [w:] Bibliotekarstwo polskie...., s. 295.

${ }^{169}$ Cyt. za Kondek, Papierowa..., s. 95.

170 TD ZDK BN, 80c, Projekt Uchwały Krajowej Narady Działaczy KulturalnoOświatowych odbytej w Warszawie 20 i 21 listopada 1956 roku. 
Zgodnie z tym założeniem księgozbiory biblioteczne miały „zerwać więzy społeczne z narodowym dziedzictwem kultury" ${ }^{171}$. W efekcie kultura, nauka i oświata polska poniosły nieodwracalne szkody spowodowane m.in. „wycofaniem” z powszechnego obiegu czytelniczego wydawnictw uznanych przez władze za bezwartościowe i szkodliwe.

Dekret o bibliotekach ... pozwolił na stworzenie sieci kilku tysięcy bibliotek publicznych, trwale opartej na podziale administracyjnym kra$\mathrm{ju}^{172}$. I to należy przypisać J. Gryczowi jako niewątpliwą zasługę. Przy tym, z biegiem czasu, zwiększała się liczba placówek prowadzonych przez bibliotekarzy posiadających wykształcenie fachowe ${ }^{173}$. Przede wszystkim jednak wbrew oczekiwaniom władz biblioteki nie stały się w pełni „modelarniami nowego ustroju”, ponieważ wydawnictwa „wartościowe ideologicznie i politycznie" zapełniające ich księgozbiory nie odegrały takiej roli, jaką przypisywała im partia ${ }^{174}$.

${ }^{171}$ A. Kempa, Literatura źle obecna, „Poradnik Bibliotekarza”, 1989, nr 5, s. 29.

172 P. Lechowski, Problemy..., s. 111.

${ }^{173}$ Ciekawą informację na temat poziomu wykształcenia ogólnego ówczesnych bibliotekarzy zawiera załącznik (datowany na 30 listopada 1953 r.) do projektu Uchwały Krajowej Narady Dziataczy Kulturalno-Oświatowych odbytej w Warszawie 20 i 21 listopada 1956 roku. H. Kraszewski opisywał w nim stan bibliotekarstwa publicznego w województwie warszawskim. Informował m.in., że pochodzenie społeczne bibliotekarzy „nie budzi zastrzeżeń. Bibliotekarzy pochodzenia robotniczego jest 38,6\%, chłopskiego 45\%, inteligencji pracującej 13,4\% i rzemieślniczego 2,2\%. Natomiast stosunkowo dużo jest bezpartyjnych 52,4\%. Do ZMP należy 31,4\% ogółu bibliotekarzy. PZPR - 8,4\% [....]. Poziom wykształcenia ogólnego bibliotekarzy jest niezadawalający. Mamy dużą ilość bibliotekarzy i to przeważnie w gminnych bibliotekach, którzy mają tylko ukończoną szkołę podstawową, 35,7\% w stosunku do ogółu pracowników. Natomiast w stosunku do ilości gminnych pracowników to wynosi $60,3 \%$. Jeżeli jeszcze dodamy procent bibliotekarzy, którzy nie mają ukończonej szkoły podstawowej - 3,4\%, [...] należy zachęcić bibliotekarzy gminnych do podniesienia swoich kwalifikacji ogólnych w myśl wskazań IX Plenum KC. PZPR. Z pełnym wykształceniem średnim mamy $30 \%$ ogółu bibliotekarzy [....] z wyższym [....] prawie 3\%, a z niepełnym 2,5\% ogółu bibliotekarzy”. Autor postulował także podniesienie poziomu wykształcenia zawodowego i wyszkolenia ideologicznego pracowników bibliotek.

${ }^{174}$ Kondek, Papierowa..., s. 102-108 i in.; tenże, Czytelnik bez właściwości. Miejsce czytelnictwa w państwowym obiegu książki w latach 1949-1955, „Rocznik Biblioteki Narodowej”, 32:1996, s. 57-86. 


\section{Streszczenie}

\section{Prace Józefa Grycza nad organizacja bibliotekarstwa publicznego w latach 1945-1949 Część II}

Tekst stanowi drugą część artykułu opublikowanego w t. 5 „Z badań nad książką i księgozbiorami historycznymi” z 2011 r. W pierwszej części przedstawiono udział Józefa Grycza w pracach nad Dekretem o bibliotekach i opiece nad zbiorami historycznymi wydanym 17 kwietnia 1946 r. Część druga poświęcona została działalności J. Grycza jako Naczelnego Dyrektora Bibliotek (NDB) w zakresie realizacji zapisów Dekretu dotyczących bibliotekarstwa publicznego. W szczególności zajmuje się problemem doboru, kontroli i „oczyszczania” księgozbiorów bibliotek. Kwestia ta rzutowała na ocenę przez władze prowadzenia ,akcji bibliotecznej” przez NDB i na ich opinię o pracy samego J. Grycza. Kolejna część artykułu dotyczy budowy sieci samorządowych bibliotek publicznych oraz uwarunkowań, zwłaszcza politycznych i finansowych, wpływających na jej przebieg. Tekst zamyka fragment analizujący zmiany jakie zaszły w bibliotekarstwie po zwolnienia J. Grycza z NDB w lutym 1949 r. i po objęciu nadzoru nad „akcją biblioteczną” przez Wydział Oświaty i Kultury Komitetu Centralnego Polskiej Zjednoczonej Partii Robotniczej

\section{Summary}

\section{Józef Grycz's Organizational Input into the Process of Reconstructing Public Libraries after the Second World War (1945-1949) Part II}

Part I of this article (published in the previous volume) discussed Józef Grycz's input into the preparation of the „Library and Library Collections Decree”, issued by the Polish Interim Government, on 17 December 1946. Part II deals first with his efforts as Director General of Libraries in Poland, regarding the implementation of the aforementioned decree with respect to public libraries. The author is interested especially in issues such as: choice of books for the libraries, control of the content of the collections, and „cleansing” of libraries of politically inappropriate books. All these issues had immediate impact on the evaluation of the activities of the Office of the General Director of Libraries, and J. Grycz personally by his Communist superiors. The latter part of the article looks into his works on creating the network of local self-government libraries, and especially the financial and political conditions of their establishing. The article is concluded with a short overview of what happened after Grycz's dismissal in February 1949, and after the introduction of direct supervision of library activities in Poland by the Department of Enlightenment and Culture of the Central Committee of the Polish United Workers' Party (the Communist Party). 
